In cooperation with the Edwards Aquifer Authority

\title{
Evaluation of Acoustic Doppler Velocity Meters to Quantify Flow From Comal Springs and San Marcos Springs, Texas
}

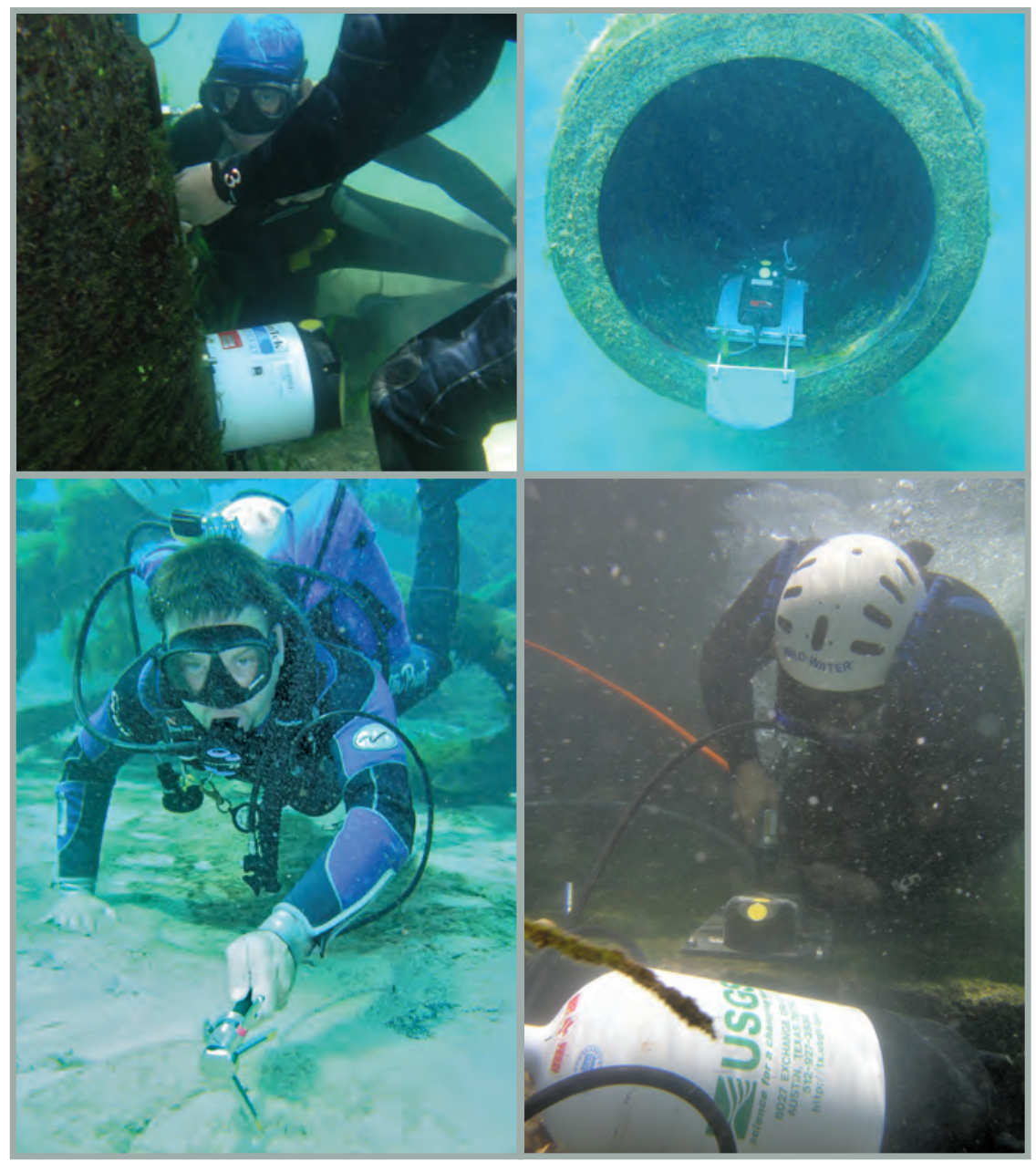

Scientific Investigations Report 2008-5083 


\section{Cover:}

Top left, U.S. Geological Survey divers installing Argonaut SL on left bank of west outflow channel of Spring Lake, San Marcos.

Top right, Argonaut SW installed inside steel pipe over diversion spring at San Marcos Springs.

Bottom left, U.S. Geological Survey diver testing velocity data acquisition in one of the spring sand boils of San Marcos Springs using an Argonaut ADV 3-D. Photograph by Tom Wiles.

Bottom right, U.S. Geological Survey divers installing acoustic Doppler velocity meter at Comal Springs new channel gage station. 


\section{Evaluation of Acoustic Doppler Velocity Meters to Quantify Flow From Comal Springs and San Marcos Springs, Texas}

By Marcus 0. Gary, Robin H. Gary, and William H. Asquith

In cooperation with the Edwards Aquifer Authority

Scientific Investigations Report 2008-5083 


\section{U.S. Department of the Interior DIRK KEMPTHORNE, Secretary}

\section{U.S. Geological Survey \\ Mark D. Myers, Director}

\section{U.S. Geological Survey, Reston, Virginia: 2008}

For product and ordering information:

World Wide Web: http://www.usgs.gov/pubprod

Telephone: 1-888-ASK-USGS

For more information on the USGS—-the Federal source for science about the Earth, its natural and living resources, natural hazards, and the environment:

World Wide Web: http://www.usgs.gov

Telephone: 1-888-ASK-USGS

Any use of trade, product, or firm names is for descriptive purposes only and does not imply endorsement by the U.S. Government.

Although this report is in the public domain, permission must be secured from the individual copyright owners to reproduce any copyrighted materials contained within this report.

Suggested citation:

Gary, M.O., Gary, R.H., and Asquith, W.H., 2008, Evaluation of acoustic Doppler velocity meters to quantify flow from Comal Springs and San Marcos Springs, Texas: U.S. Geological Survey Scientific Investigations Report 2008-5083,

$37 \mathrm{p}$. 


\section{Contents}

Abstract fntroduction
Purpose and Scope
Previous Acoustic Doppler Velocity Meter Applications
Physical Setting
Comal Springs

Figure 1.1. Hydrograph showing all stream velocity data collected using acoustic Doppler velocity meters at monitoring sites at Comal Springs, New Braunfels, Texas

Figure 1.2. Hydrograph showing all stream velocity magnitude data collected using acoustic Doppler velocity meters at monitoring sites at San Marcos Springs, San Marcos, Texas 
Figure 1.3. Listing of $\mathrm{R}$ code for computation of a mean velocity correction factor for bypass pipe at station 08168932 Comal River (new channel) near Landa Lake, New Braunfels, Texas, based on pipe geometry and settings of Argonaut SW

\section{Figures}

1-3. Maps showing:

1. San Antonio segment of the Edwards aquifer, Texas, and locations of Comal and San Marcos Springs ... .2

2. Locations of monitoring sites at Comal Springs 3

3. Locations of monitoring sites at San Marcos Springs

4-7. Photographs showing:

4. U.S. Geological Survey diver testing velocity data acquisition in one of the spring sand boils of San Marcos Springs using an Argonaut ADV 3-D . .8

5. Argonaut $S W$ installed on right-bank wall, midway down run of spring run 3 at Comal Springs . .8

6. Argonaut ADV 2-D installed with acoustic sensors oriented to make pointvelocity measurements of water flowing from spring 7 at Comal Springs .9

7. U.S. Geological Survey diver installing Argonaut SW just upstream of 61-footwide weir on new channel of Comal River

8. Schematic showing location of data-collection platform (DCP) and both acoustic Doppler velocity meters (ADVM) (one in front of weir and one in bypass pipe) at new channel of Comal River

9-10. Photographs showing:

9. View of new channel of Comal River looking upstream as bypass gate valve is being closed by U.S. Geological Survey staff member

10. Acoustic Doppler velocity meter installed in old channel of Comal River seen (circled in yellow) as small black area with two yellow circles (transducers), 7 feet upstream from concrete and stone bridge and upstream from culverts

11. Schematic showing location of acoustic Doppler velocity meter (ADVM) in old channel of Comal River

12-15. Photographs showing:

12. U.S. Geological Survey diver approaching steel pipe structure over diversion spring during acoustic Doppler velocity meter installation

13. View of cave orifice through 26-inch-diameter pipe at diversion spring

14. Biota net installed on steel pipe structure at diversion spring at San Marcos Springs

15. Argonaut SW installed inside steel pipe over diversion spring at San Marcos Springs

16. Schematic showing diversion spring cave at San Marcos Springs, pipe assembly covering spring, and location of acoustic Doppler velocity meter (ADVM) inside pipe.

17-20. Photographs showing:

17. View looking downstream from west outflow channel of Spring Lake, San Marcos 
18. U.S. Geological Survey divers installing Argonaut SL on left bank of west outflow channel of Spring Lake, San Marcos

19. Argonaut SW installed in east outflow channel of Spring Lake, San Marcos .......17

20. Argonaut SW installed at station 08170500 San Marcos River at San Marcos attached to bridge pier in primary channel of flow

21. Schematic showing location of acoustic Doppler velocity meter (ADVM) next to bridge pier at station 08170500 San Marcos River at San Marcos

22-37. Graphs showing:

22. Velocity magnitude from spring run 3 at Comal Springs and streamflow from station 08169000 Comal River at New Braunfels during acoustic Doppler velocity meter deployment

23. Velocity magnitude from spring run 3 at Comal Springs and streamflow from station 08169000 Comal River at New Braunfels, January 2007

24. Velocity magnitude from spring 7 at Comal Springs and streamflow from station 08169000 Comal River at New Braunfels during acoustic Doppler velocity meter deployment

25. Velocity magnitude from spring 7 at Comal Springs and streamflow from station 08169000 Comal River at New Braunfels, November 2006

26. Velocity magnitude from spring 7 at Comal Springs and streamflow from station 08169000 Comal River at New Braunfels, March-April 2007

27. Velocity magnitude over weir and in bypass pipe from new channel of Comal River; gage height at weir from new channel of Comal River; and streamflow from station 08169000 Comal River at New Braunfels during acoustic Doppler velocity meter deployment

28. Velocity magnitude over weir and in bypass pipe from new channel of Comal River, and gage height at weir from new channel of Comal River during bypass valve experiment

29. Velocity magnitude over weir from new channel of Comal River; gage height at weir from new channel of Comal River; and streamflow from station 08169000 Comal River at New Braunfels, June-July 2007

30. Velocity magnitude and gage height from old channel of Comal River during acoustic Doppler velocity meter deployment

31. Velocity magnitude and gage height from old channel of Comal River showing influence of debris and anthropogenic control on streamflow

32. Velocity magnitude in pipe from diversion spring at San Marcos Springs and streamflow from station 08170500 San Marcos River at San Marcos during acoustic Doppler velocity meter deployment

33. Velocity magnitude from west outflow of Spring Lake and streamflow from station 08170500 San Marcos River at San Marcos during acoustic Doppler velocity meter deployment

34. Velocity magnitude from east outflow of Spring Lake and streamflow from station 08170500 San Marcos River at San Marcos during acoustic Doppler velocity meter deployment

35. Velocity magnitude from east outflow of Spring Lake and streamflow from station 08170500 San Marcos River at San Marcos, March 7-21, 2007

36. Velocity, gage height, and streamflow from station 08170500 San Marcos River at San Marcos during acoustic Doppler velocity meter deployment

37. Streamflow from station 08170500 San Marcos River at San Marcos, August 1-0ctober 31, 2006 


\section{Table}

1. Acoustic Doppler velocity meter sites at Comal Springs, New Braunfels, Texas, and San Marcos Springs, San Marcos, Texas 


\title{
Evaluation of Acoustic Doppler Velocity Meters to Quantify Flow From Comal Springs and San Marcos Springs, Texas
}

\author{
By Marcus 0. Gary, Robin H. Gary, and William H. Asquith
}

\section{Abstract}

Comal Springs and San Marcos Springs are the two largest springs in Texas, are major discharge points for the San Antonio segment of the Edwards aquifer, and provide habitat for several Federally listed endangered species that depend on adequate springflows for survival. It is therefore imperative that the Edwards Aquifer Authority have accurate and timely springflow data to guide resource management. Discharge points for Comal Springs and San Marcos Springs are submerged in Landa Lake and in Spring Lake, respectively. Flows from the springs currently (2008) are estimated by the U.S Geological Survey in real time as surface-water discharge from conventional stage-discharge ratings at sites downstream from each spring. Recent technological advances and availability of acoustic Doppler velocity meters (ADVMs) now provide tools to collect data (stream velocity) related to springflow that could increase accuracy of real-time estimates of the springflows. The U.S. Geological Survey, in cooperation with the Edwards Aquifer Authority, did a study during May 2006 through September 2007 to evaluate ADVMs to quantify flow from Comal and San Marcos Springs. The evaluation was based on two monitoring approaches: (1) placement of ADVMs in important spring orifices_-spring run 3 and spring 7 at Comal Springs, and diversion spring at San Marcos Springs; and (2) placement of ADVMs at the nearest flowing streams-Comal River new and old channels for Comal Springs, Spring Lake west and east outflow channels and current (2008) San Marcos River streamflow-gaging site for San Marcos Springs. For Comal Springs, ADVM application at spring run 3 and spring 7 was intended to indicate whether the flows of spring run 3 and spring 7 can be related to total springflow. The findings indicate that even though velocity data from both discharge features reflect changes in flow, the data do not reliably show a direct relation to measured streamflow and thus to total Comal Springs flow. ADVMs at the Comal River new channel and old channel sites provide data that potentially could yield more accurate real-time estimates of total Comal Springs flow than streamflow measured at the downstream Comal River site. For San Marcos Springs, the findings indicate shortcomings with ADVM installations at diversion spring and in the west and east outflow channels. However, the accuracy of streamflow measured at the San Marcos River gage as an estimate of real-time San Marcos Springs flow could potentially be increased through use of ADVM data from that site.

\section{Introduction}

Comal Springs in Comal County and San Marcos Springs in Hays County are the two largest springs in Texas and are major discharge points for the San Antonio segment of the Edwards aquifer (fig. 1). This segment of the Edwards aquifer is the principal source of municipal and agricultural water in the San Antonio region and also is the sole habitat for a number of Federally listed endangered species (Crowe and Sharp, 1997). Springs such as Comal and San Marcos are natural outflow features that reflect the condition and water levels of the aquifer. This is especially true in karst settings such as the Edwards aquifer because water-level changes in multiple spatial and temporal scales are rapidly reflected in changes in flow from the springs. Therefore, accurate and continual quantification of springflow is a primary tool for assessing the condition of karst aquifers and aquatic habitats.

Springflows (discharges) of Comal and San Marcos Springs indicate critical aquifer conditions relative to the survival of several endangered species. Crowe and Sharp (1997) reported that appreciable alterations to habitats of endangered species in these springs will occur if springflows decrease to low rates. The U.S. Fish and Wildlife Service (1996) has defined low (jeopardy) springflows for the Federally listed endangered fountain darter at Comal and San Marcos Springs to be 150 and 100 cubic feet per second, respectively. When springflows decrease below the jeopardy flow thresholds, the Edwards Aquifer Authority (EAA) initiates restrictions on withdrawals (pumping) of water from the aquifer. It is therefore imperative that the EAA have accurate and timely springflow data to guide resource management.

The EAA has identified improving methods of flow measurement at Comal and San Marcos Springs as a priority (Geary Schindel, Edwards Aquifer Authority, oral commun., 


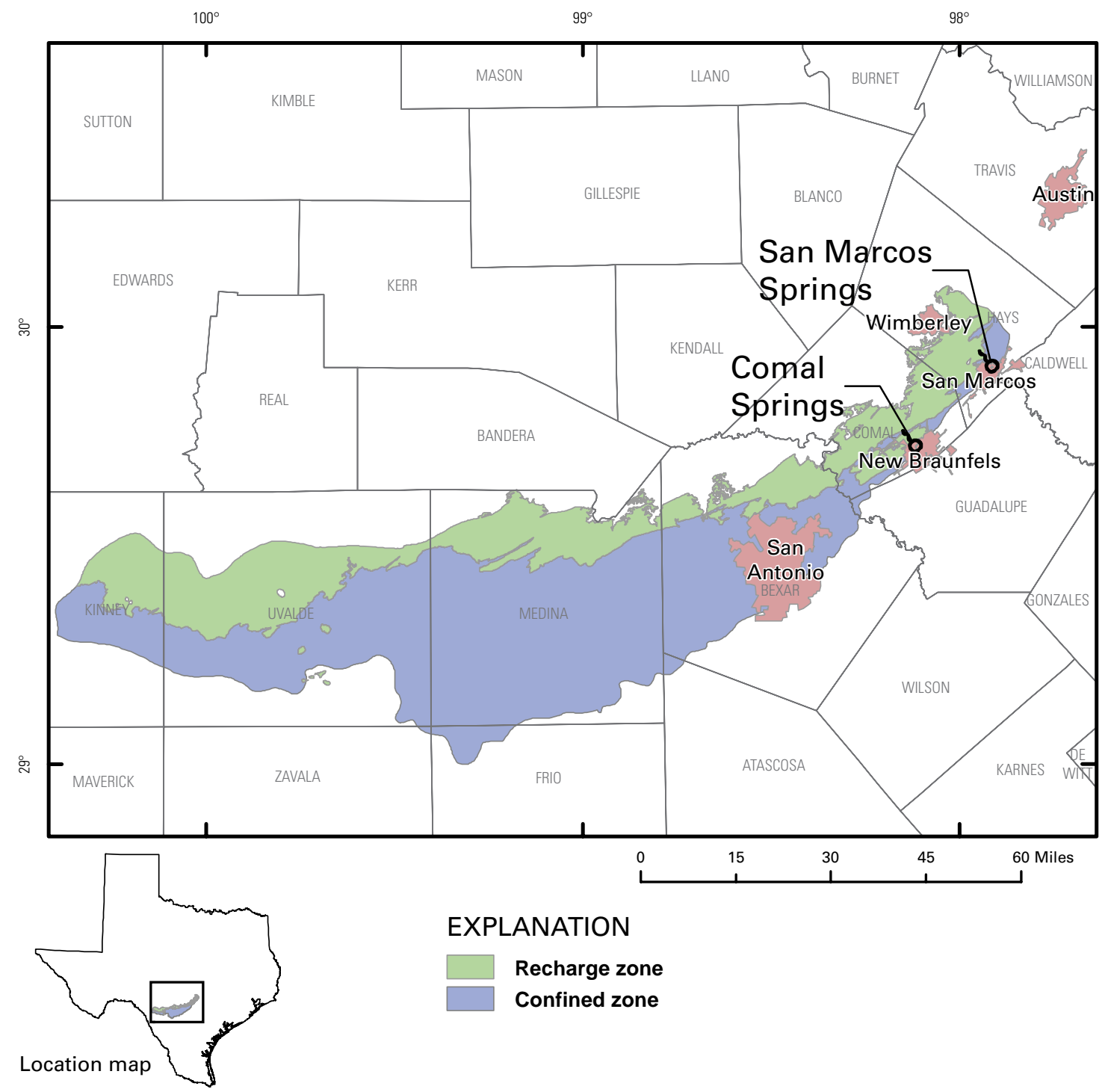

Figure 1. San Antonio segment of the Edwards aquifer, Texas, and locations of Comal and San Marcos Springs.

2005). Measurement of flow directly from the spring orifices has been technically difficult or impossible because (1) there are many distributed and focused discharge points at Comal and San Marcos Springs, and (2) many springs are submerged in Landa Lake at Comal Springs and in Spring Lake at San Marcos Springs.

Flow from Comal Springs currently (2008) is estimated by the U.S Geological Survey (USGS) in real time as streamflow computed from a conventional stage-discharge rating at USGS station (site) 08169000 Comal River at New Braunfels. This station is about 1.6 miles downstream from the major spring orifices at Landa Lake (fig. 2). The stage-discharge rating is a relation between water-surface elevation (stage or gage height) in the channel and discharge; the rating is developed and maintained by periodic streamflow measurements over a range of heights in the channel (Rantz and others, 1982).
The real-time estimates of springflow are useful for timely aquifer-management decisions; however, using streamflow at station 08169000 as a direct estimate of springflow has several drawbacks that can result in an inaccurate record of true springflow: (1) Inflow of local surface-water runoff and base flow downstream from Comal Springs and upstream from the gaging station can cause estimated springflow to be artificially high. (2) Evaporation from the 1.6-mile stream reach between the springs and station 08169000 might cause estimated spring discharge to be artificially low. (3) Underflow of water through permeable streambed rocks might cause estimated spring discharge to be artificially low because this underflow is not measured during direct discharge measurements. Accordingly, the USGS estimates daily mean springflow of Comal Springs, although not in real time, as (1) streamflow at station 08169000 when runoff and base flow are essentially negligible, and (2) streamflow at 


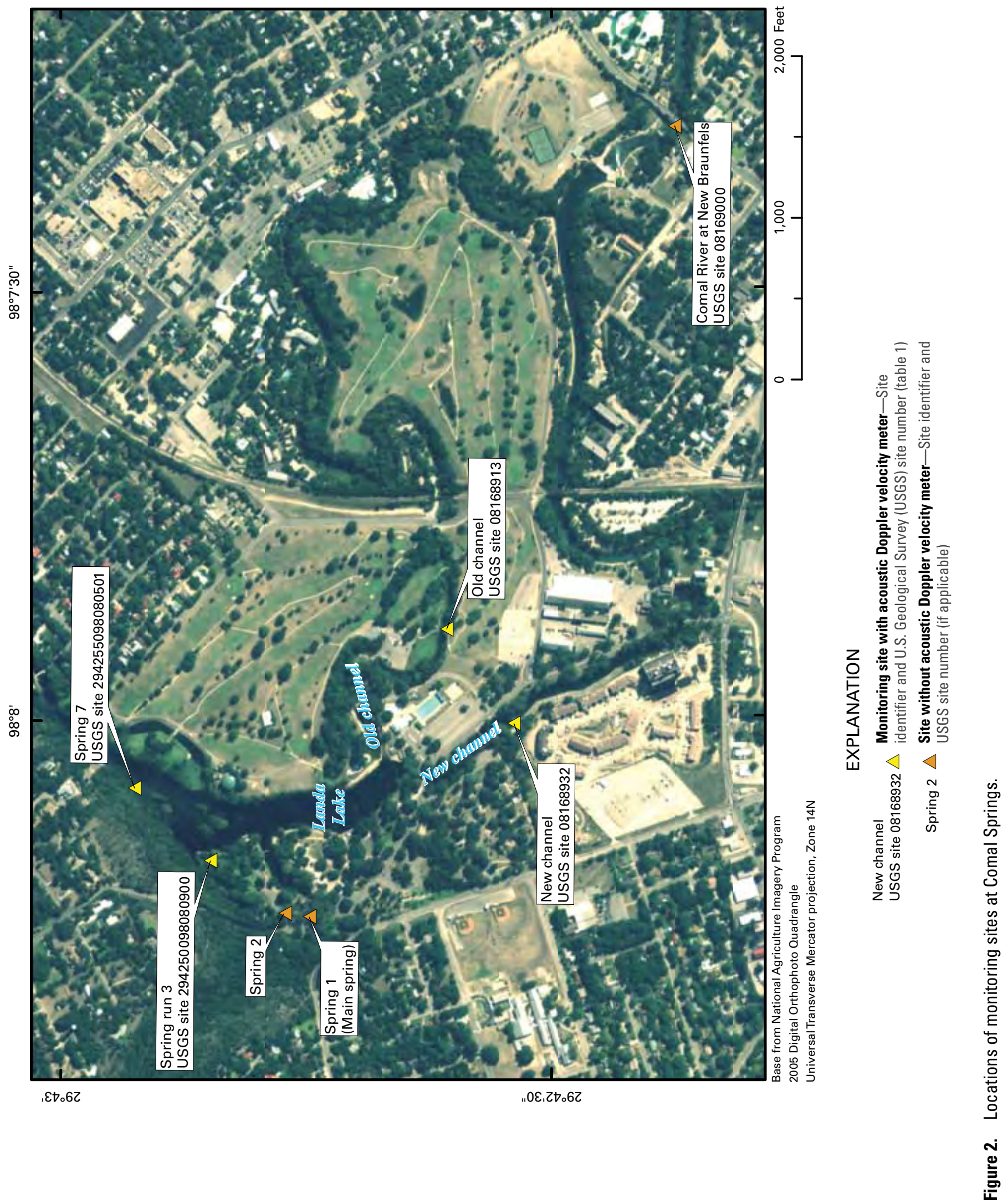




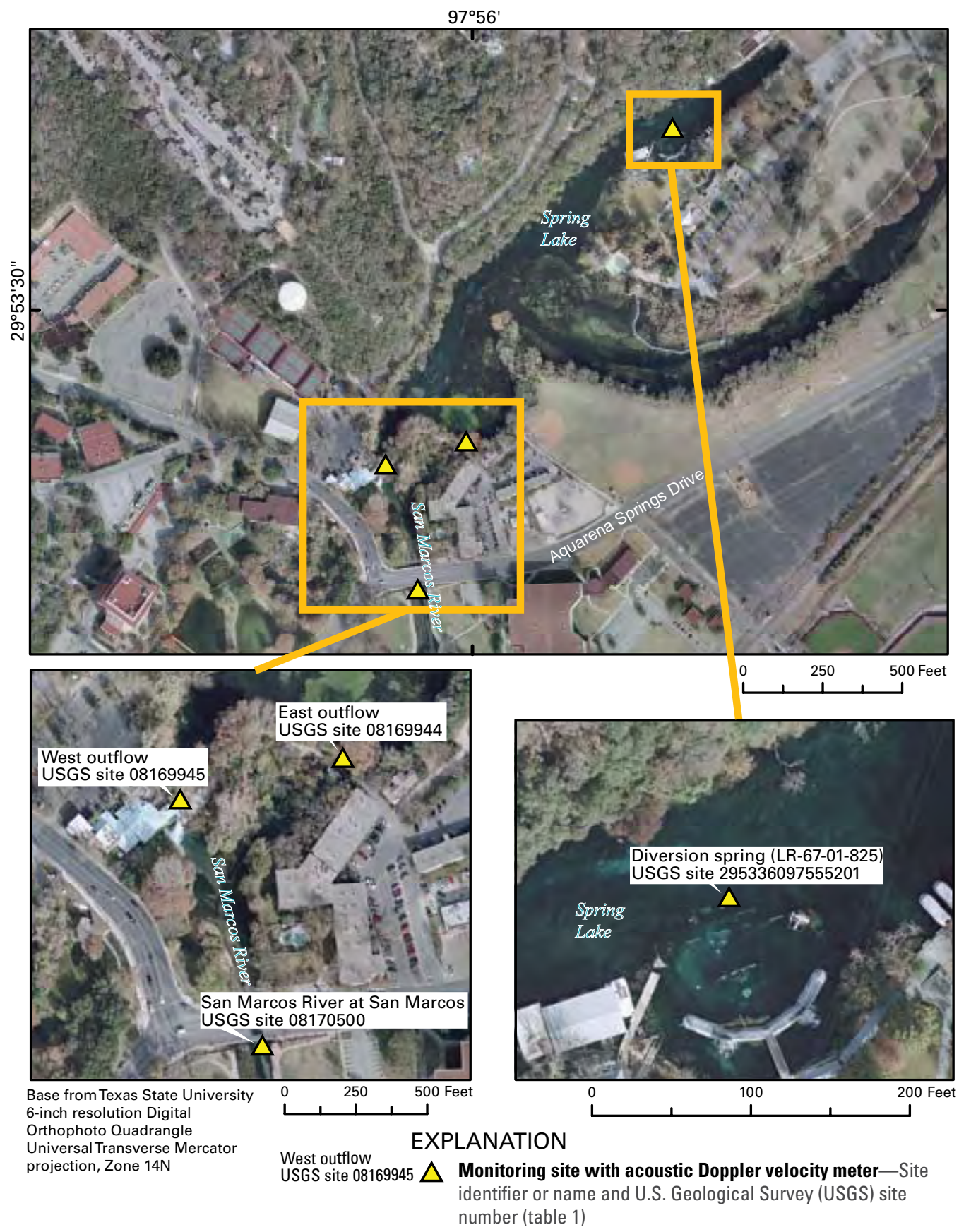

Figure 3. Locations of monitoring sites at San Marcos Springs.

station 08169000 adjusted using computerized base-flow separation techniques described by Wahl and Wahl (1995) that depend on water levels in nearby index wells when runoff and base flow are not negligible. This non-real-time springflow record is archived under station 08168710 Comal Springs at New Braunfels (station number for archival purposes only), and the record comprises only daily mean values.

As with Comal Springs monitoring, the USGS estimates real-time flow from San Marcos Springs as streamflow computed from stage-discharge ratings at station 08170500 San Marcos River at San Marcos, which is about 0.5 mile downstream from Spring Lake (fig. 3). Daily mean springflow is estimated by accounting for base flow in the stream reach between Spring Lake and the gage using the computerized base-flow separation techniques of Wahl and Wahl (1995). This non-real-time daily mean springflow record is archived under station 08170000 San Marcos Springs at San Marcos (station number for archival purposes only), and the record comprises only daily mean values. 
Recent technological advances and availability of acoustic Doppler velocity meters (ADVMs) now provide tools to collect stream velocity data related to springflow that could increase accuracy of real-time estimates of flow from Comal and San Marcos Springs. ADVMs use the Doppler-shift principle to reliably measure the velocity of water (Morlock and others, 2002; U.S. Geological Survey, 2007). Several instrument configurations are available from different manufacturers. Each instrument configuration provides measurements appropriate for specific environmental conditions. The velocity of water flowing through a specific cross-sectional area can be directly related to discharge through this area. ADVM velocity data for sites at Comal and San Marcos Springs have the potential to complement and possibly replace the stage-discharge ratings for the Comal River and the San Marcos River streamflow-gaging sites. Accordingly, the USGS, in cooperation with the EAA, did a study during May 2006 through September 2007 to evaluate ADVMs to quantify flow from Comal and San Marcos Springs, with the overall objective of improving measurement of total springflow.

\section{Purpose and Scope}

This report documents the monitoring approaches applied using ADVMs, describes the monitoring sites, and evaluates the performance of ADVMs with regard to increasing the accuracy of real-time records of springflow for Comal and San Marcos Springs. Eight sites were equipped with ADVMs for periods of months during 2006-07 to evaluate the performance of ADVMs: one ADVM each at three sites and two ADVMs at one site at Comal Springs; and one ADVM each at four sites at San Marcos Springs. The study focused on two approaches to monitoring springflow with ADVMs: one involved placing ADVMs at important spring orifices to measure flow directly at discrete discharge points; and the other involved placing ADVMs at the nearest flowing streams to measure total spring discharge as outflow from the impounded lakes fed by the springs.

\section{Previous Acoustic Doppler Velocity Meter Applications}

ADVMs commonly are applied at USGS gaging stations across the United States, and standard methods have been developed to use the velocity data to compute flow records (Morlock and others, 2002). The application of ADVMs in karst springs has been successfully tested at station 08155500 Barton Springs at Austin (Asquith and Gary, 2005; Gary and Asquith, 2005, 2006) and at station 08170990 Jacob's Well Spring near Wimberley (Gary and Asquith, 2006; Gary, 2007). At both sites, ADVMs were placed in discrete discharge orifices or underwater caves. Acoustic velocity data collected at Barton Springs were used to augment the official discharge record during storms when stage data alone were insufficient or unreliable to monitor springflow. The application of
ADVMs at Barton Springs and Jacob's Well Spring provided background information for this report and identified strengths and weaknesses of ADVM applications in karst springs.

\section{Physical Setting}

\section{Comal Springs}

Comal Springs is the largest spring in the State with an average long-term (December 1927-September 2007) discharge of 291 cubic feet per second (U.S. Geological Survey, 2008, station 08168710). The springs emerge from a number of discrete orifices in and around Landa Lake (fig. 2). These individual orifices discharge directly into Landa Lake and are identified as two distinct groups of springs that discharge from separate flow systems. Spring 1 (main spring), spring 2, and spring 3 (spring run 3 ) flow into stream runs and are thought to represent a shallow flow system. Spring 7 and numerous other springs on the northern segment of Landa Lake are thought to emerge from a deep flow system (Kreitler and others, 2004; LBG Guyton Associates, 2004).

The total spring discharge from Comal Springs is integrated into short-term storage in Landa Lake. Landa Lake discharges through two separate stream channels. The original (old channel) stream from Landa Lake exits on the southeastern edge of the lake and flows through a swimming pool through a series of valves and locks. Flow through the swimming pool can be diverted to a separate channel for pool draining and cleaning or periods of non-use. During summer when the pool is open for recreation, it is drained weekly for cleaning. A new outflow channel from Landa Lake was constructed to supply water to a power plant and is now the major discharge feature from the lake. Based on direct discharge measurements made on July 2, 2007, and July 30,2007 , about 85 percent of the total outflow from Landa Lake is through the new channel. The old and new channels merge with the Comal River about 1 river mile downstream from Landa Lake. The station 08169000 Comal River at New Braunfels that is used to quantify springflow from Comal Springs is about 900 feet downstream from the confluence.

\section{San Marcos Springs}

San Marcos Springs is the second largest spring in the State with an average long-term (May 1955-September 2007) discharge of 175 cubic feet per second (U.S. Geological Survey, 2008, station 08170000). Similar to Comal Springs, San Marcos Springs consists of a number of focused and diffuse discharge sites. These sites include discrete orifices and numerous sand boils at the bottom of Spring Lake (fig. 3). LBG Guyton Associates (2004) estimated that about 25 percent of the total flow from San Marcos Springs emerges from discrete orifices and the remaining 75 percent from sand boils. 
The water flowing from San Marcos Springs collects in the impounded Spring Lake and discharges over two separate outflow structures as the headwaters of the San Marcos River. The San Marcos Spring Lake west overflow (west outflow) channel exits over a series of waterfalls with variable-height gates that can control the water-surface elevation in Spring Lake and thus the rate of flow out of the lake. The San Marcos Spring Lake east overflow (east outflow) channel flows over a concrete control structure and then over boulders. The two channels converge below the outfall structures and immediately upstream from the Aquarena Springs Drive bridge.

The concrete dam that impounds Spring Lake is located between the two outflow structures and likely allows a substantial amount of underflow. On May 11, 2006, measurements made on both outflow structures (west overflow and east overflow) yielded a total flow of 107 cubic feet per second. Measurements made downstream from the confluence of the two channels yielded a total flow of 130 cubic feet per second. The downstream measurements indicate that, on that day, about 18 percent of the flow from San Marcos Springs passed beneath the dam. Station 08170500 San Marcos River at San Marcos, which is used to quantify flow from San Marcos Springs in real time, is at the Aquarena Springs Drive bridge. The streambed at this site is prone to substantial changes in vegetation density and gravel movement. These changes can influence the stage-discharge rating for the site, which makes the site challenging with regard to using a conventional stagedischarge rating to estimate streamflow.

\section{Acoustic Doppler Velocity Meters}

An ADVM is an instrument that operates underwater to measure the velocity of water as it passes the device. It uses the Doppler-shift principle applied to sound waves underwater relative to moving particles suspended in the water column.

\section{Principles of Operation}

ADVMs use one or more monostatic acoustic transducers, oriented in a known, fixed position, that transmit and receive underwater sound waves. The transducers produce pulses of sound at a specific frequency in a narrow acoustic beam. As particles in the water pass through the beam, the sound pulses bounce off the particles, scattering the sound pulses and reflecting some back to the transducer. The reflected pulses have a frequency shift that is proportional to the velocities of the particles from which they were reflected. Thus the velocity of moving particles is measured, and water surrounding these particles is assumed to travel at the same velocity (Morlock and others, 2002; SonTek Corporation, 2000). The acoustic beam transmitted from the ADVM can be programmed by the user to compute velocity in a set part of the beam (referred to as sample volume or cell). The velocity measured in this sample volume is a mean velocity of all sound pulses received by the transducer.
Each transducer on an ADVM is capable of producing one-dimensional velocity data for moving particles in the water column. For instance, a single transducer can measure values in the $\mathrm{x}$-direction (relative to a set datum orientation). Because water flow seldom is one-dimensional, additional transducers are added to an ADVM to acquire data in additional dimensions. An ADVM with two transducers yields a two-dimensional measurement ( $\mathrm{x}$ and y components), and an ADVM with three transducers yields a three-dimensional measurement ( $\mathrm{x}, \mathrm{y}$, and $\mathrm{z}$ components). The orientation of the coordinate system is relative to the mounting orientation of the ADVM. A typical two-transducer ADVM will produce acoustic velocity data with magnitudes of both the $\mathrm{x}$ (downstream) and y (lateral or cross-stream) components. All ADVMs collect velocity data for a set period defined by the user, known as the averaging interval. The length of the averaging interval is determined by the number of independent acoustic velocity measurements that are averaged to produce a single value for recording. In clear water, averaging intervals are longer as fewer particles are present to return a strong acoustic signal. The longer averaging interval allows for a statistically more precise velocity measurement.

\section{Description of Models Used}

Four models of ADVMs were tested in the study, all manufactured by SonTek Corporation, San Diego, Calif. The Argonaut SW (shallow water) was used at most evaluation sites. This ADVM is a two-dimensional instrument for open-channel and pipe flow monitoring with a compact, rugged design that enables flexible deployment. A third acoustic transducer on the instrument allows for water-level measurements to be recorded when the instrument is mounted on the bottom of a stream channel. The Argonaut SW has a resolution of 0.003 foot per second and can measure velocities as high as 16 feet per second (SonTek Corporation, 2007). The acoustic transducers transmit at a frequency of 3 megahertz and have a maximum sample-cell range of 16 feet. The Argonaut SW is equipped to vary the sample-cell length dynamically as water depths change.

Three ADVM units were used for specified applications. The Argonaut SL (side looker) also operates with a resolution of 0.003 foot per second, transmitting frequency of 3 megahertz, and maximum sample-cell range of 16 feet (SonTek Corporation, 2007). The Argonaut SL uses two acoustic transducers (is two-dimensional) and averages water velocity laterally across the stream channel. It also has a third acoustic transducer that measures water level above the instrument. The Argonaut ADV 2-D has a resolution of 0.003 foot per second, transmits at a 5-megahertz frequency, and has a small sample volume of 0.015 cubic inch. It is designed to give a precise point-velocity measurement about 0.5 inch upstream from the instrument in a narrow flow structure such as a discrete spring orifice. The Argonaut ADV 3-D is a threedimensional, self-powered, hand-held version of the Argonaut ADV. 
All units tested are capable of self-logging with internal memory or communicating directly to a data-collection platform (DCP) by way of SDI-12 (serial digital interface) communication protocol, which is the global standard for interfacing data-loggers with microprocessor-based sensors. The $\mathrm{x}$-vector, $\mathrm{y}$-vector, and resultant velocity magnitude data are collected and logged with other diagnostic information including data related to signal strength. Temperature measurements also are standard on all models.

\section{Methods of Study}

\section{Monitoring Approaches}

The evaluation of ADVMs at Comal Springs and San Marcos Springs is based on two monitoring approaches: (1) placement of ADVMs in important spring orifices to measure ground-water velocity at discrete discharge points, and (2) placement of ADVMs at the nearest flowing streams to measure total springflow as surface-water outflow from Landa Lake and Spring Lake. The first approach relies on the hypothesis that a single ground-water discharge orifice or feature would be representative of the total springflow of the system, and thus changes in the velocity and resulting flow from this feature would be related to changes in the total springflow of the system. Two sites at Comal Springs, spring run 3 and spring 7 (fig. 2), and one site at San Marcos Springs, diversion spring (fig. 3), were monitored using this approach. Discharge from sand boils was measured at the discharge point by a diver using the hand-held Argonaut ADV 3-D (fig. 4). Testing indicated that three-dimensional velocity vectors are too variable in the sand boils to produce useful time-series data; therefore, no continuous monitoring was done at sand boils.

The second approach involves more standard methods of stream gaging to quantify total flow from the springs. At Comal Springs, new streamflow gages with ADVMs were installed in the new channel and the old channel (fig. 2) as close to Landa Lake as site characteristics permitted. At San Marcos Springs, both outflow channels at Spring Lake (fig. 3) were instrumented with ADVMs, as well as existing station 08170500. In all, eight sites were monitored (table 1), four at Comal Springs (two in spring orifices and two at stream sites) and four at San Marcos Springs (one in a spring orifice and three at stream sites).

\section{Description of Monitoring Sites and Instrumentation}

\section{Comal Springs—Spring Run 3}

Springflow emerging from the left bank and bottom of the channel of spring run 3 represents about 13 percent of the total springflow from Comal Springs (LBG Guyton
Associates, 2004). The run is about 300 feet long, and the channel gains streamflow from numerous springs along the run. The regular geometry of the channel midway down the spring run provided an adequate site to mount an Argonaut SW to the 2-foot-high rock wall on the right bank (fig. 5). The ADVM was programmed to sample water velocity across the entire width of the channel minus a 6-inch "blanking distance" next to the instrument and a 1-foot section adjacent to the left bank. An averaging interval of 300 seconds (5 minutes) was used to produce and record data values every 15 minutes. The $\mathrm{x}$ (downstream) and y (lateral) components of flow were measured, and a resultant velocity magnitude was computed. Data were recorded in the ADVM, using the internal logging capabilities of the instrument. ADVM monitoring at this site was intended to indicate whether flow (estimated from velocity and stage) of spring run 3 could be related to total springflow.

\section{Comal Springs-Spring 7}

About 600 feet north of spring run 3, a discrete discharge point referred to as spring 7 flows from a small underwater cave. The spring is in limestone bedrock and extends a minimum of 5 feet into the rock. An Argonaut ADV 2-D was anchored to the limestone above the water surface with the acoustic probe extending into the middle of the spring orifice underwater (fig. 6). The instrument measured the $x$ (downstream) and y (lateral) components of flow velocity and computed a resultant velocity magnitude. A 0.015-cubic-inch sample volume 3.9 inches from the probe sensors provided a point-velocity measurement, as opposed to a large spatially averaged velocity measurement that would have been provided by the Argonaut SW. An averaging interval of 600 seconds (10 minutes) was used to produce and record a data value every 15 minutes. As with data from spring run 3, ADVM monitoring at this site was intended to indicate whether flow at spring 7 is related to changes in total springflow.

\section{Comal Springs-New Channel}

The new channel of the Comal River passes over a lowwater, concrete weir about 800 feet downstream from Landa Lake (fig. 7). The concrete weir is 61 feet wide. A 42-inch bypass pipe with a gate valve is located on the left bank of the weir. Two Argonaut SW instruments were installed at this site to monitor the flow over the weir and through the bypass pipe (fig. 8). The primary instrument is mounted 5 feet upstream from the weir, 20 feet from the left bank (fig. 7); flow characteristics at the mounting location measured by a flowmeter indicate this location is minimally affected by the baffling effect of the weir wall. The weir ADVM records the velocity of water before it flows over the weir, where the flow is less turbulent than flow downstream from the weir. The instrument also uses the upward-facing transducer to record the water level. The second ADVM is mounted on the upstream segment of the bypass pipe 4 feet upstream from the gate valve. 


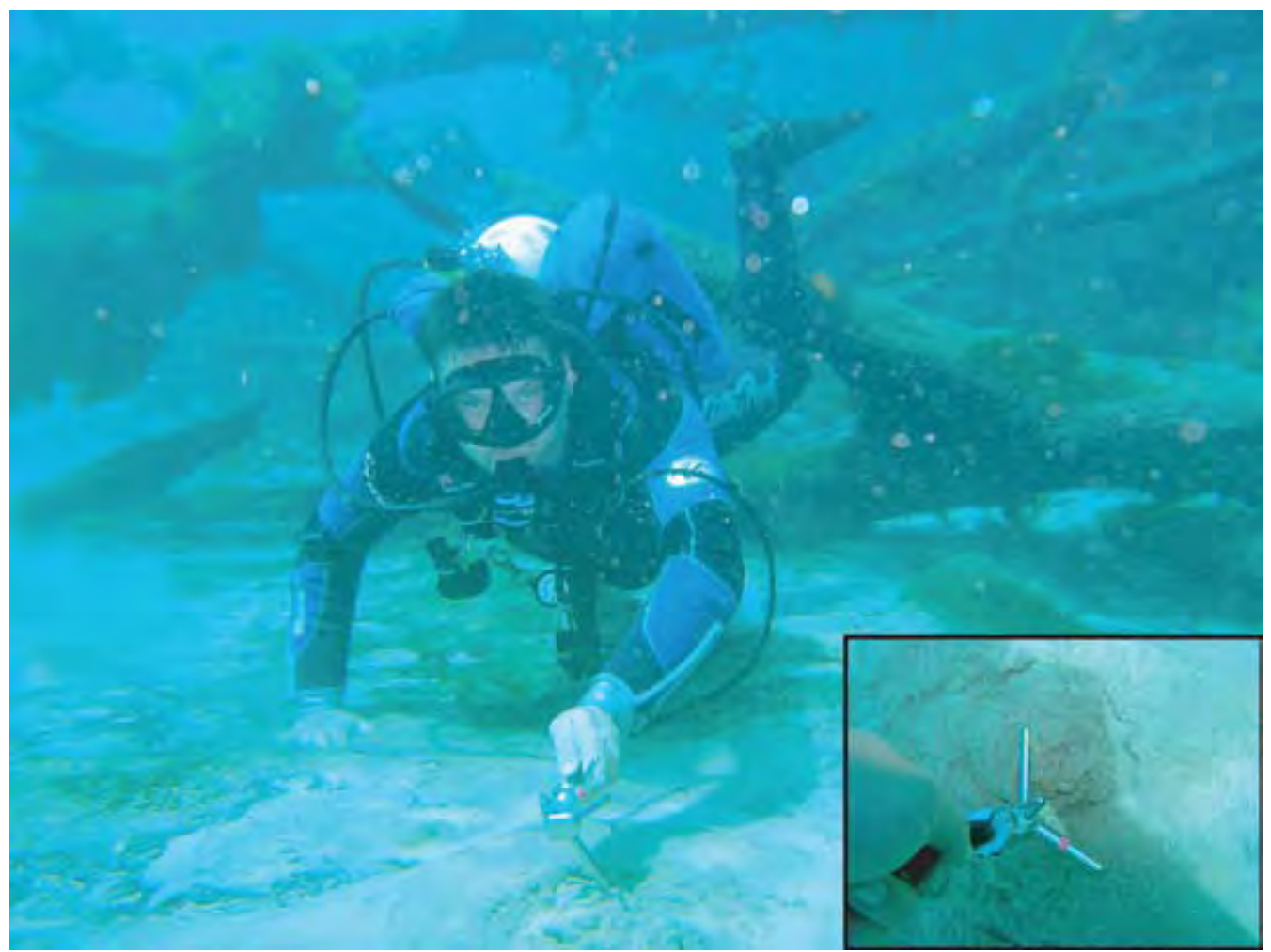

Figure 4. U.S. Geological Survey diver testing velocity data acquisition in one of the spring sand boils of San Marcos Springs using an Argonaut ADV 3-D. Inset shows close-up of sand boil being measured with hand-held acoustic Doppler velocity meter. Photograph by Tom Wiles.

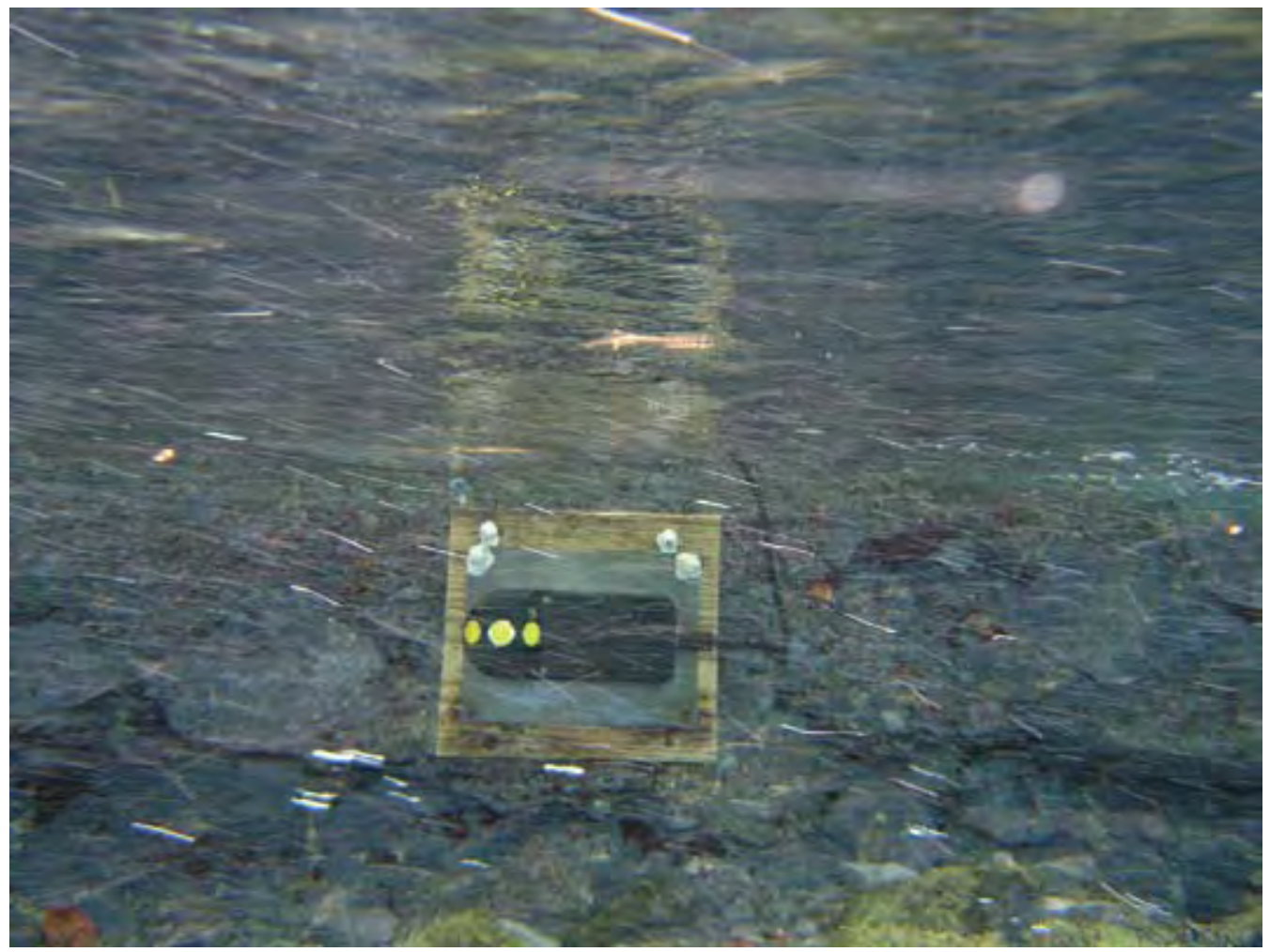

Figure 5. Argonaut SW installed on right-bank wall, midway down run of spring run 3 at Comal Springs. Instrument mounted 0.8-1.2 feet below water surface, depending on water levels, and measured water velocity across 7 -foot cross section. 


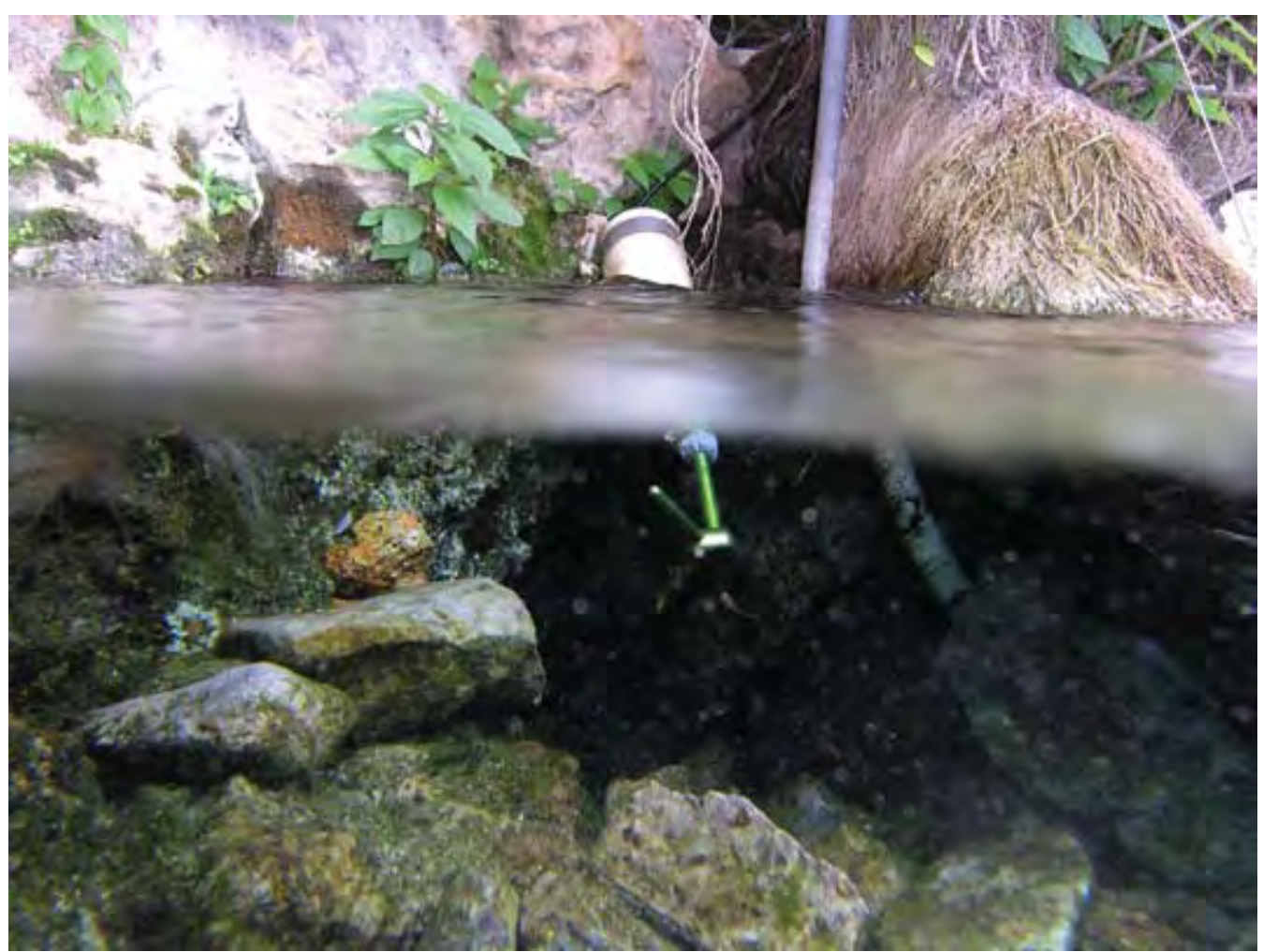

Figure 6. Argonaut ADV 2-D installed with acoustic sensors oriented to make point-velocity measurements of water flowing from spring 7 at Comal Springs.

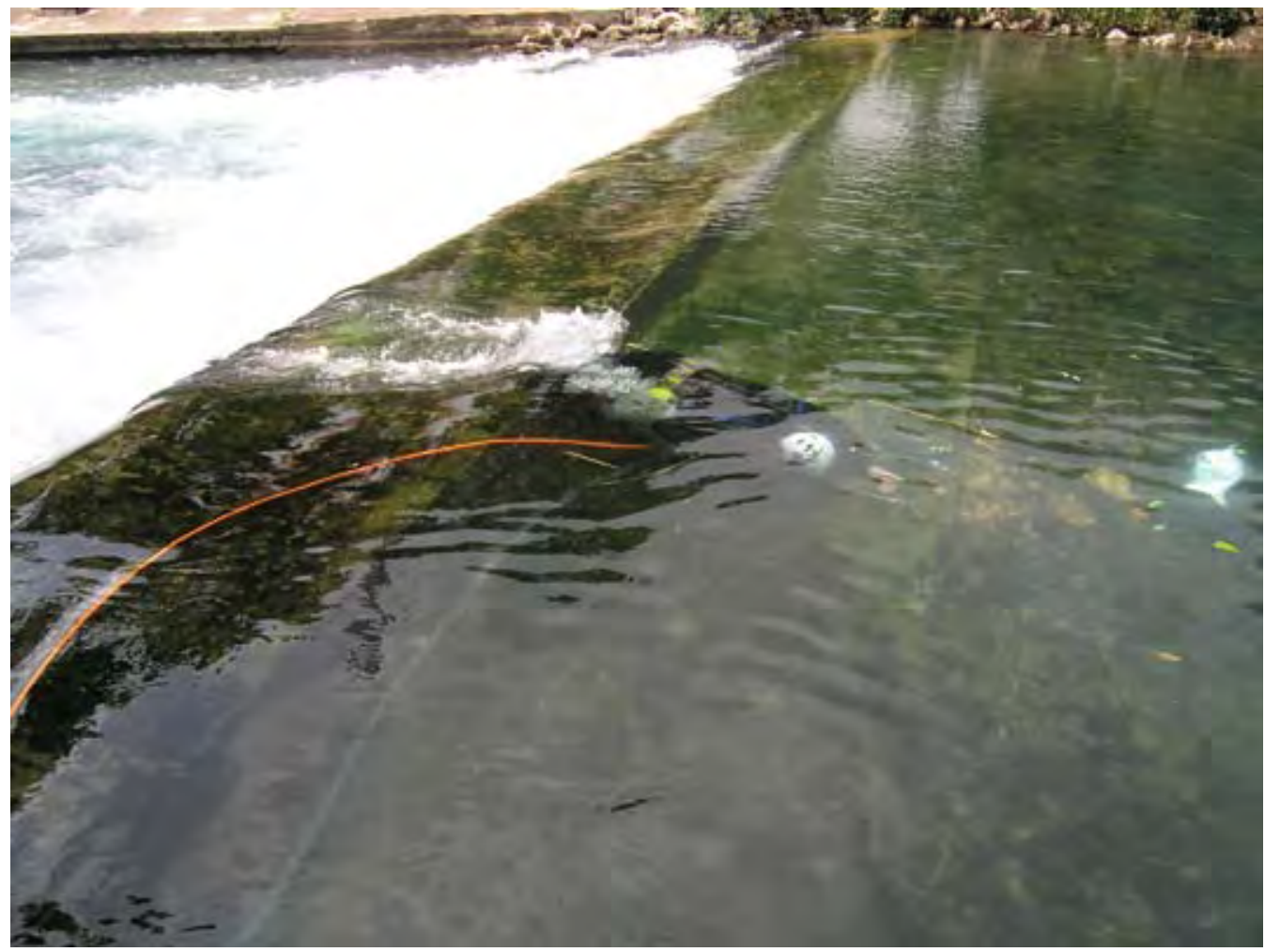

Figure 7. U.S. Geological Survey diver installing Argonaut SW just upstream of 61-foot-wide weir on new channel of Comal River. 


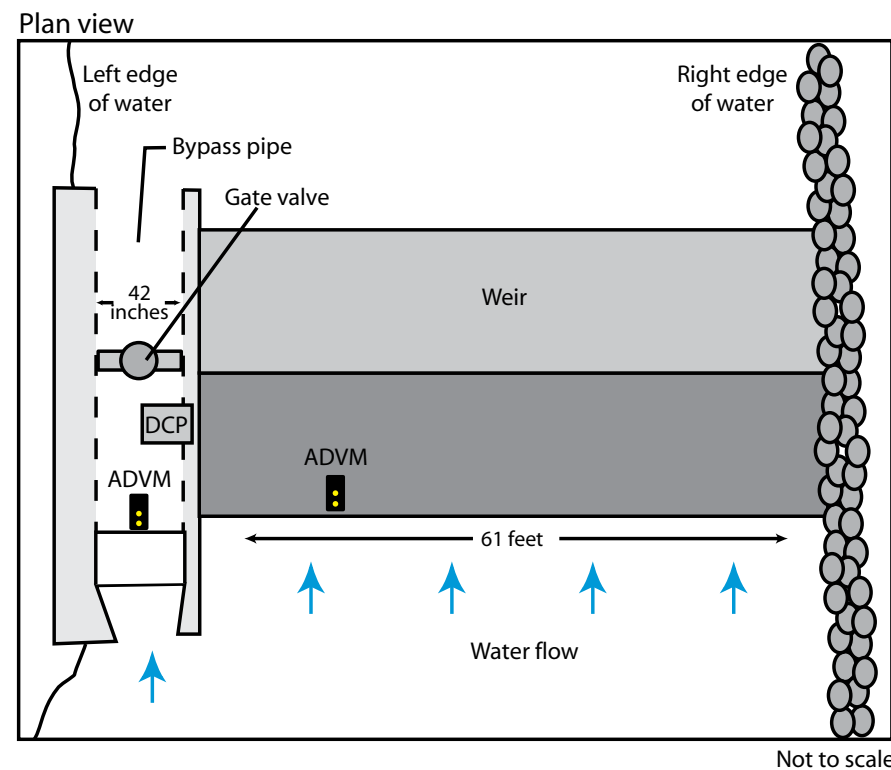

Elevation view

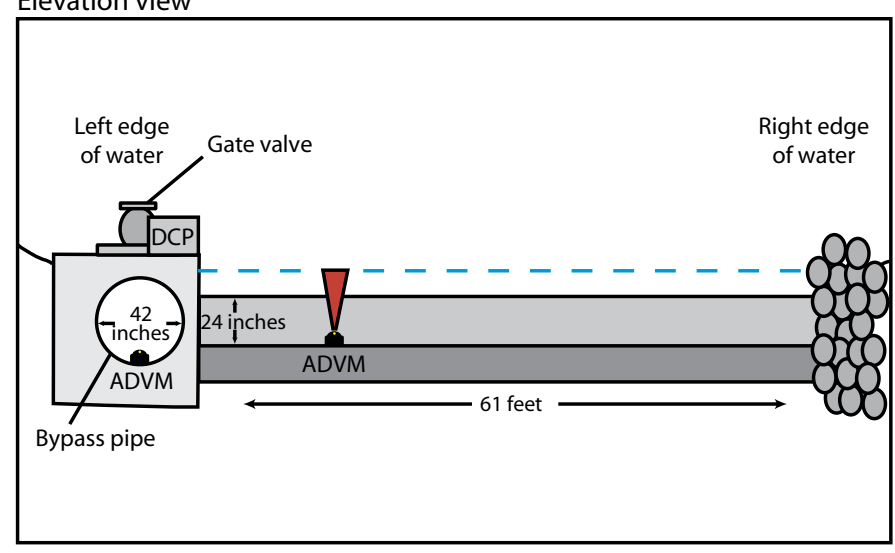

Not to scale

Figure 8. Schematic showing location of data-collection platform (DCP) and both acoustic Doppler velocity meters (ADVM) (one in front of weir and one in bypass pipe) at new channel of Comal River.
The two ADVMs at the new channel of the Comal River are intended to monitor the position of the bypass valve (open, partially closed, or fully closed) and measure the flow of water over the weir. Under normal operating conditions, the bypass valve (fig. 9) is fully closed, causing all water to flow over the weir. When the bypass valve is fully closed, the weir ADVM can accurately measure total flow in the new channel. Direct discharge measurements using a flowmeter indicate that the flow is distributed evenly across the entire width of the weir, which enables reliable correlation of velocity measurements from the mounted ADVM with velocities across the channel width and the discharge at the weir. When the bypass valve is partially or fully open, some percentage of water is diverted into the pipe and can be monitored by the second ADVM. The second ADVM also can be used to indicate whether the valve is open. Both ADVMs are programmed to collect velocity and stage measurements every 15 minutes using 300-second (5-minute) averaging intervals, and record $\mathrm{x}$-component, $y$-component, and resultant velocity magnitude data. The instruments are connected to a DCP that logs and transmits data to the USGS National Water Information System (NWIS) (U.S. Geological Survey, 2008). The control structure at this site makes the site ideal for direct discharge estimation using an index-velocity rating.

\section{Comal Springs_-Old Channel}

The old channel of the Comal River flows from Landa Lake through a municipal golf course after passing the swimming pool. The streambed is mostly loose gravel and cobbles with dense bottom vegetation. The closest adequate streamgaging site to Landa Lake is immediately upstream from a golf cart bridge. This concrete and rock bridge spans two 42-inch concrete culverts through which all water flows except during large storms. An Argonaut SW was installed using a concrete pad and steel brace about 7 feet upstream from the bridge culverts, directly between them (figs. 10,11). Although the ADVM installed at this location might be affected by flow

Table 1. Acoustic Doppler velocity meter sites at Comal Springs, New Braunfels, Texas, and San Marcos Springs, San Marcos, Texas. [USGS, U.S. Geological Survey; DD, spring orifice; OF, stream channel]

\begin{tabular}{llll}
\hline \multicolumn{1}{c}{ Site identifier } & USGS site number & & \multicolumn{1}{c}{ USGS site (station) name } \\
\hline $\begin{array}{l}\text { Comal Springs } \\
\text { Spring run 3 }\end{array}$ & 294250098080900 & DX-68-23-321 & Dite type \\
Spring 7 & 294255098080501 & DX-68-23-324 & DD \\
New channel & 08168932 & Comal River (new channel) near Landa Lake, New Braunfels, Texas \\
Old channel & 08168913 & Comal River (old channel) near Landa Lake, New Braunfels, Texas & \\
& & & \\
San Marcos Springs & & & OF \\
Diversion spring & 295336097555201 & LR-67-01-825 & OF \\
West outflow & 08169945 & San Marcos Spring Lake west overflow, San Marcos, Texas \\
East outflow & 08169944 & San Marcos Spring Lake east overflow, San Marcos, Texas & OF \\
Streamflow gage & 08170500 & San Marcos River at San Marcos, Texas & OF \\
\hline
\end{tabular}




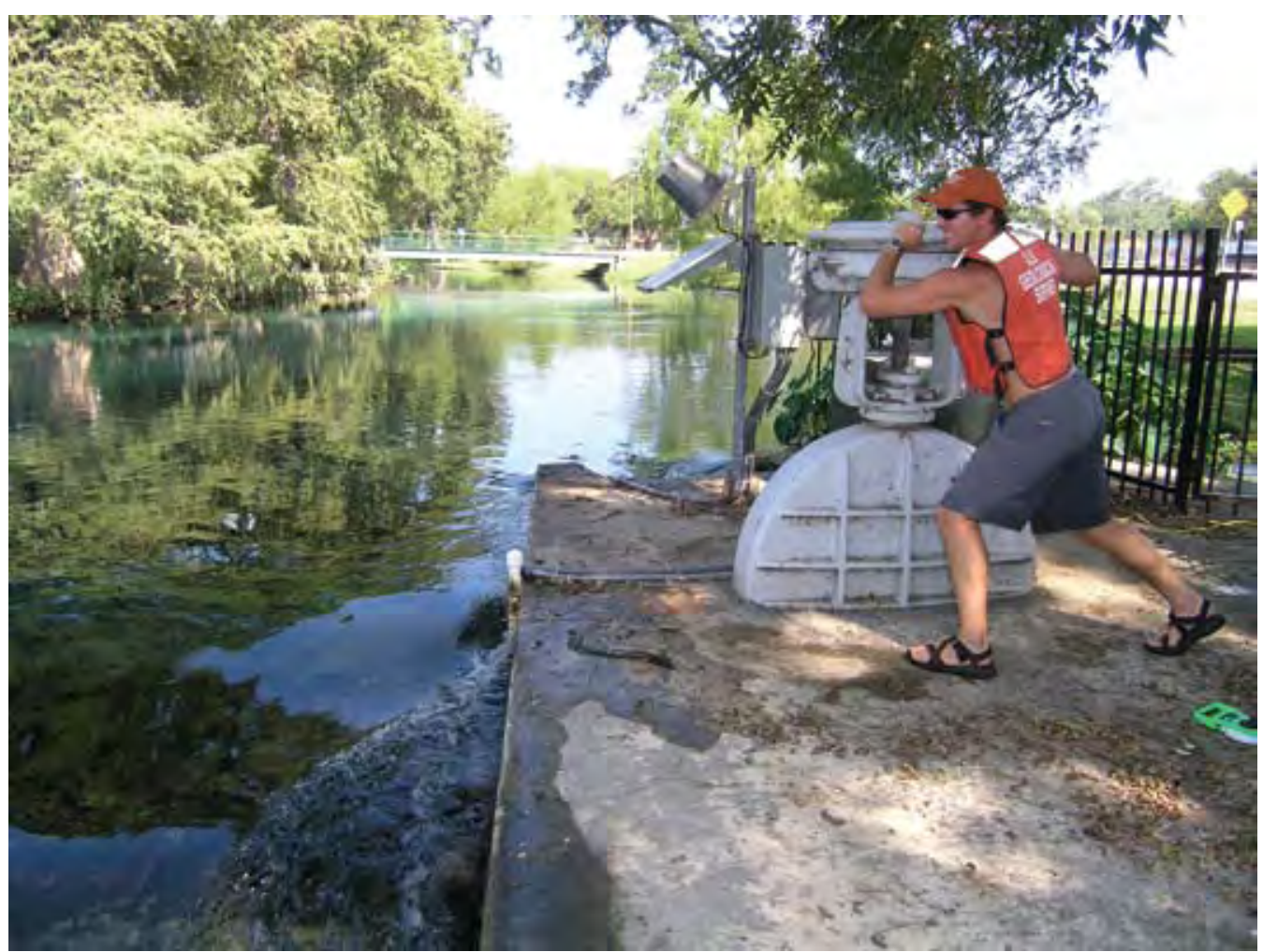

Figure 9. View of new channel of Comal River looking upstream as bypass gate valve is being closed by U.S. Geological Survey staff member. Data-collection platform seen next to valve.

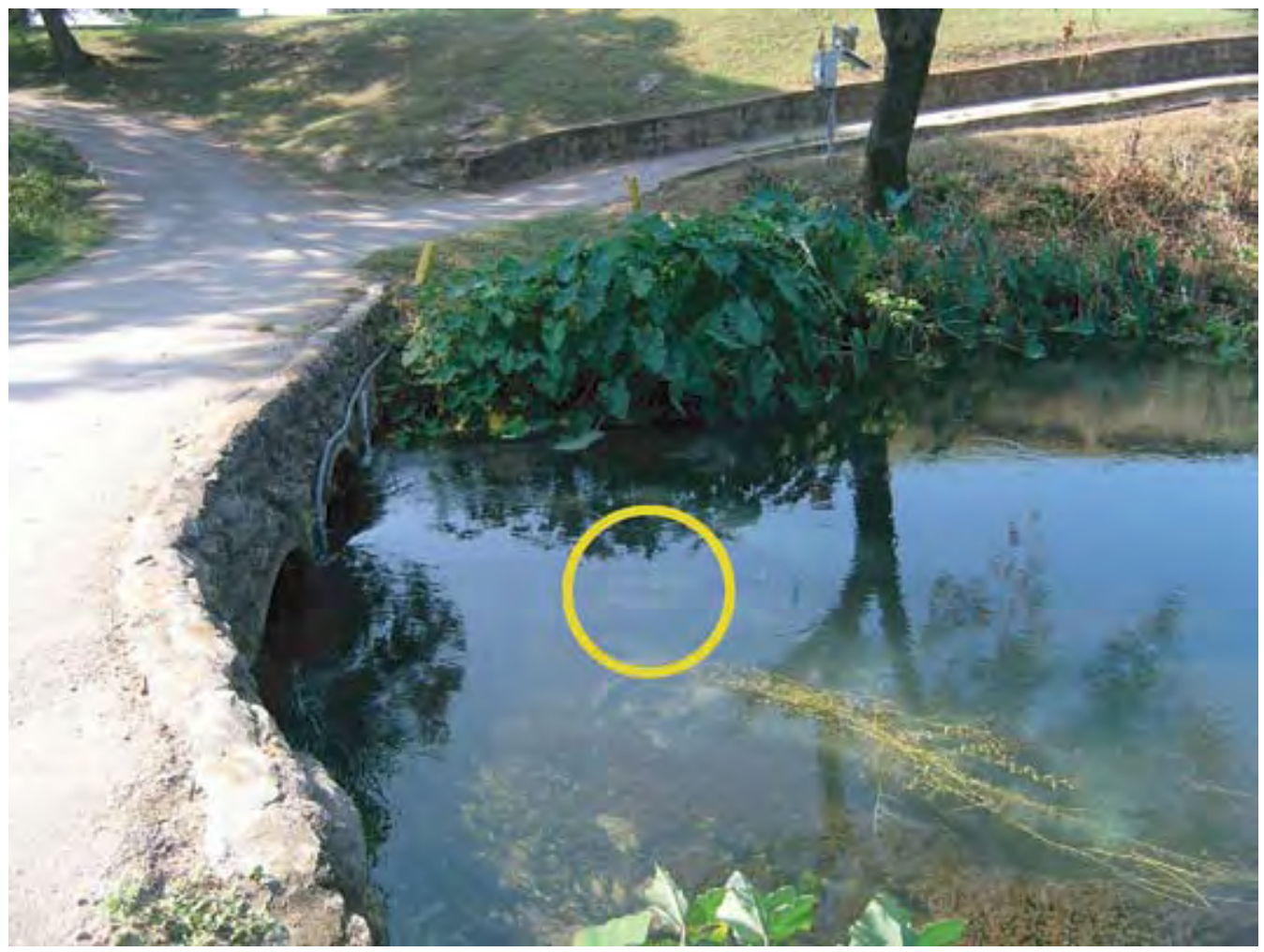

Figure 10. Acoustic Doppler velocity meter installed in old channel of Comal River seen (circled in yellow) as small black area with two yellow circles (transducers), 7 feet upstream from concrete and stone bridge and upstream from culverts. Data-collection platform seen on hill above gage. 


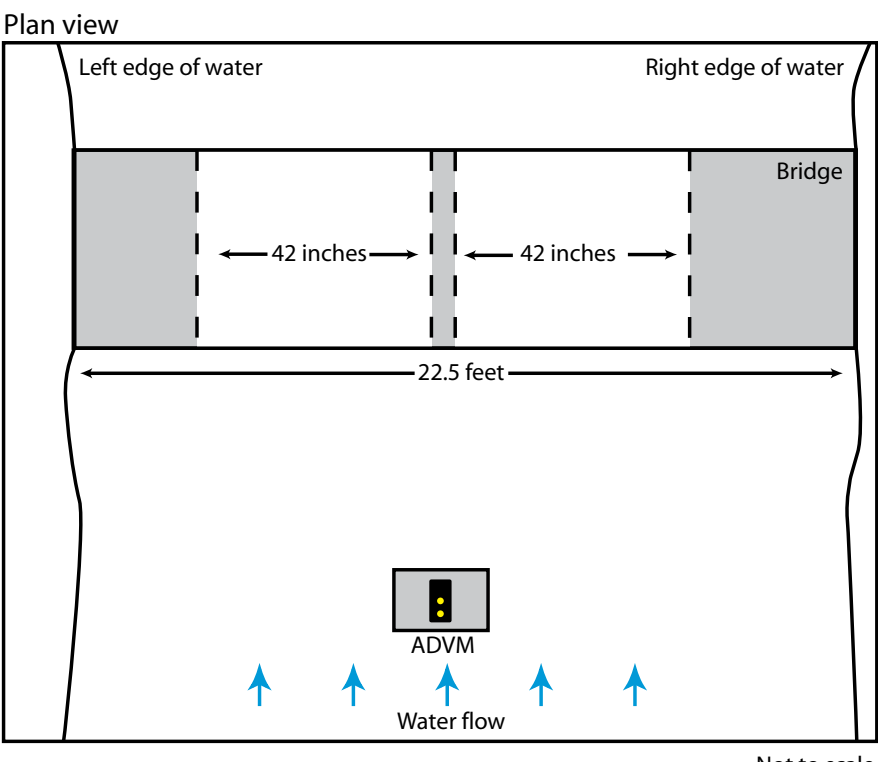

Elevation view

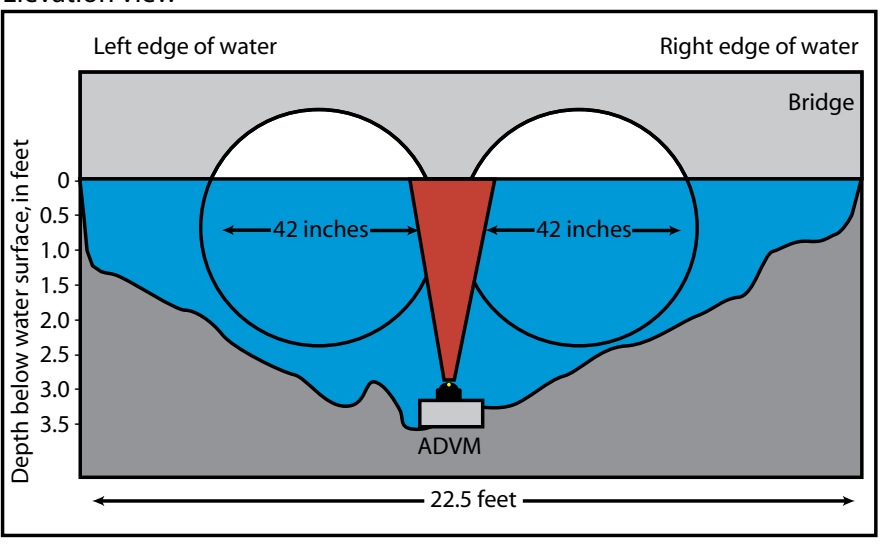

Not to scale

Figure 11. Schematic showing location of acoustic Doppler velocity meter (ADVM) in old channel of Comal River.

contraction caused by the bridge culverts, no other mounting location was practically feasible. An analysis of the velocity measurements suggests that the location and orientation of this ADVM allows for reliable monitoring of stream stage (water depth above instrument) and stream velocity. The ADVM was programmed to collect stage and velocity measurements every 15 minutes using 300-second (5-minute) averaging intervals. Data are logged in an attached DCP (fig. 10) that transmits real-time data from the site.

\section{San Marcos Springs—Diversion Spring}

Diversion spring is the largest discrete discharge orifice of San Marcos Springs, with water flowing from a cave on the bottom of Spring Lake at a depth of 22 feet (Zara Environmental LLC, 2005). A steel pipe structure about 10 feet high with a broad base (fig. 12) has been placed over the 3.5- by
1.5 -foot entrance to the orifice (fig. 13), which diverts most of the flow from the orifice through the pipe. A large net is normally on the end of the 26-inch inside diameter pipe to catch biota that flow out with spring water (fig. 14). An Argonaut SW was installed inside the pipe near the outflow when the biota net had been removed for repairs (figs. 15, 16). The ADVM measured water velocity in the pipe as it flows either directly into Spring Lake or into the biota net. Stream velocity components in the $\mathrm{x}$ and $\mathrm{y}$ directions were measured and the resultant velocity magnitude was computed by the instrument. Data were collected in 15-minute intervals with an averaging interval of 600 seconds (10 minutes) and transmitted to a DCP on the surface of Spring Lake that transmitted real-time data from the site. The data record from diversion spring was hypothesized either to correlate directly with total springflow or to identify subtle patterns of discharge from the aquifer.

\section{San Marcos Springs-West Outflow}

The west outflow channel of Spring Lake discharges water over a group of four 4-foot-wide gates (fig. 17) with boards that can be added or removed to adjust the water level of the lake as flow conditions vary. About 20 feet upstream from this gated dam, both stream banks are vertical concrete walls. The streambed is gravel and sand with moderate vegetation including the Federally endangered Texas wild rice. An Argonaut SL was installed on the left bank of the stream channel and attached directly to the concrete wall (fig. 18). The side-looking ADVM makes integrated velocity measurements across the stream channel, recording $\mathrm{x}$ and $\mathrm{y}$ components of flow and computing the resultant velocity magnitude. The instrument has an upward-facing transducer that measures the depth of water above the instrument. Data were collected in 15-minute intervals with an averaging interval of 120 seconds (2 minutes) and logged internally on the ADVM. This site was monitored to indicate whether direct gaging of the overflow was feasible.

\section{San Marcos Springs-East Outflow}

The east outflow channel of Spring Lake flows over a low-water concrete dam that provides an excellent control structure for stream gaging. Water depth over the 41 -foot-wide dam typically is less than 1 foot, and stream depth 10 feet upstream from the dam is about 1.5 feet. An Argonaut SW was installed in the east outflow channel 15 feet upstream from the dam and anchored to a concrete apron (fig. 19) and oriented to collect $\mathrm{x}$ and $\mathrm{y}$ components of flow. The instrument computed the resultant velocity magnitude and measured water depth over the instrument. Data were collected in 15-minute intervals with an averaging interval of 300 seconds (5 minutes). This site was monitored to indicate whether direct gaging here, coupled with gaging of the west outflow channel, could provide total flow from Spring Lake and thus an estimate of total springflow. 


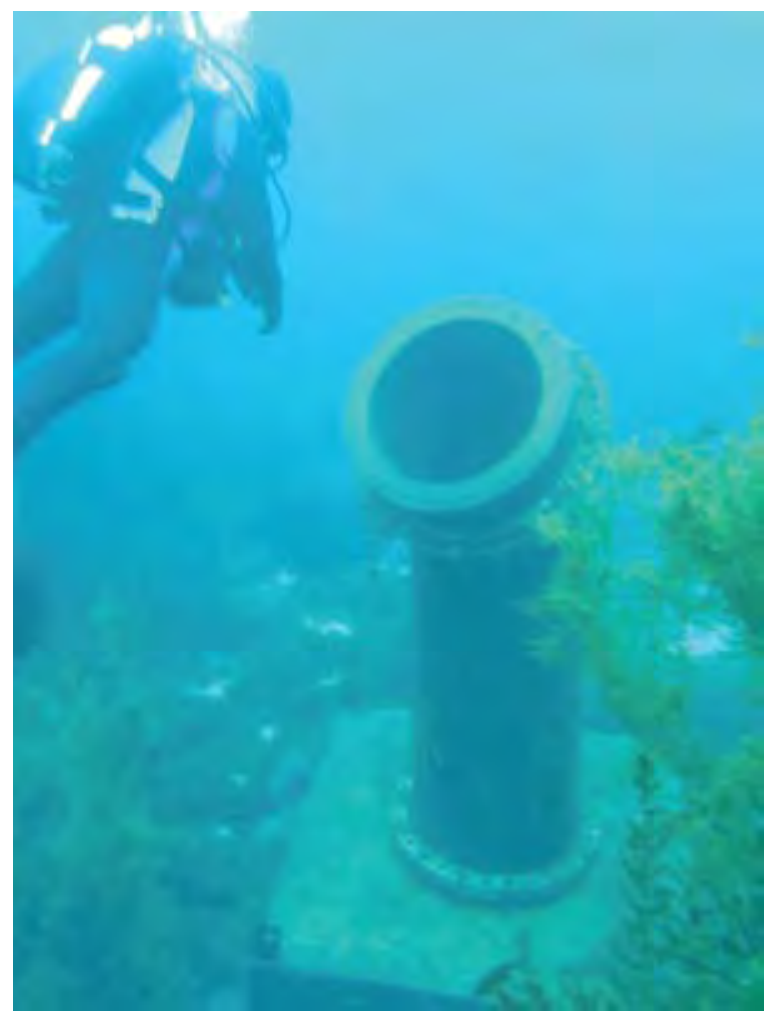

Figure 12. U.S. Geological Survey diver approaching steel pipe structure over diversion spring during acoustic Doppler velocity meter installation.

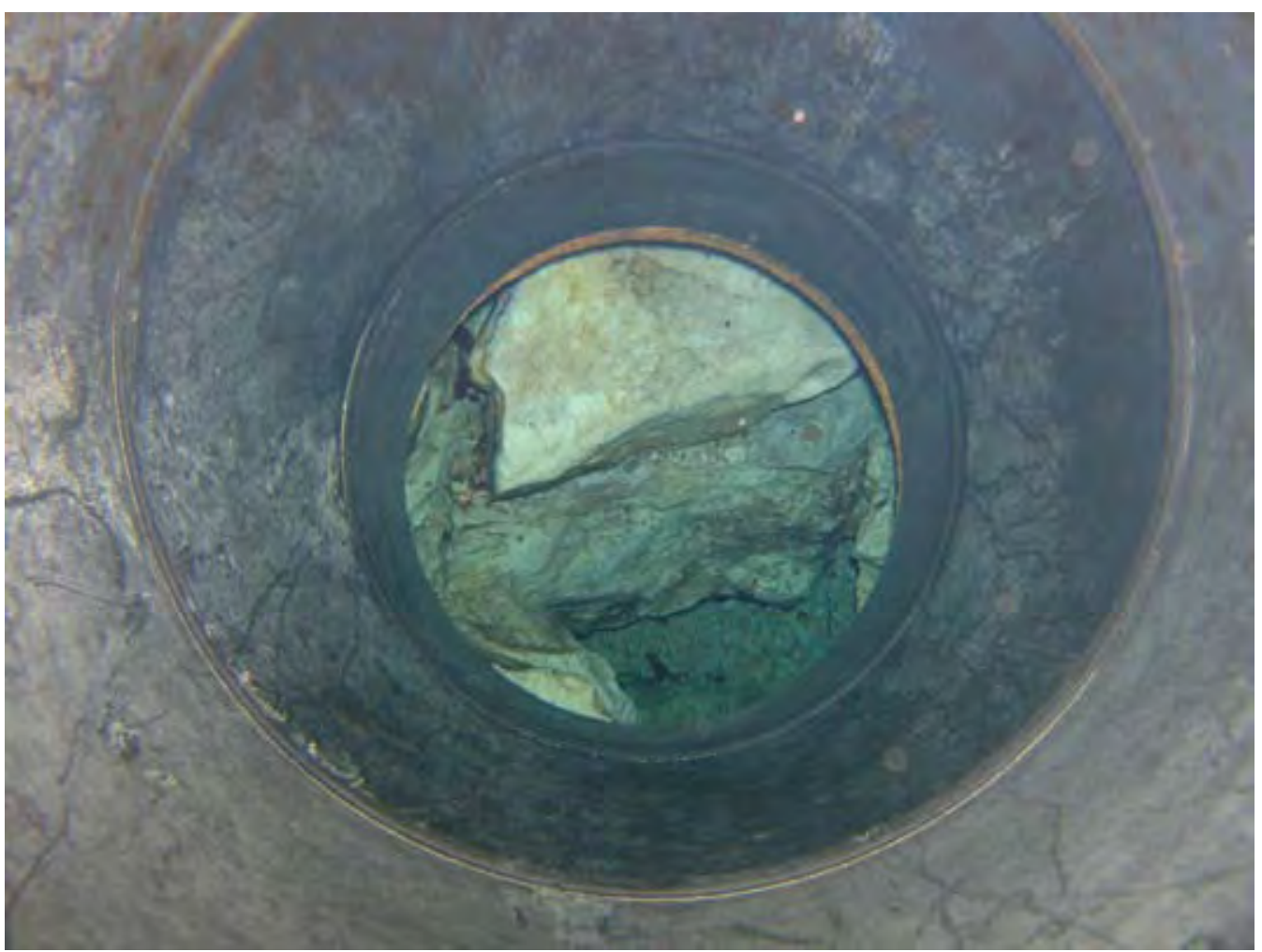

Figure 13. View of cave orifice through 26 -inch-diameter pipe at diversion spring. 


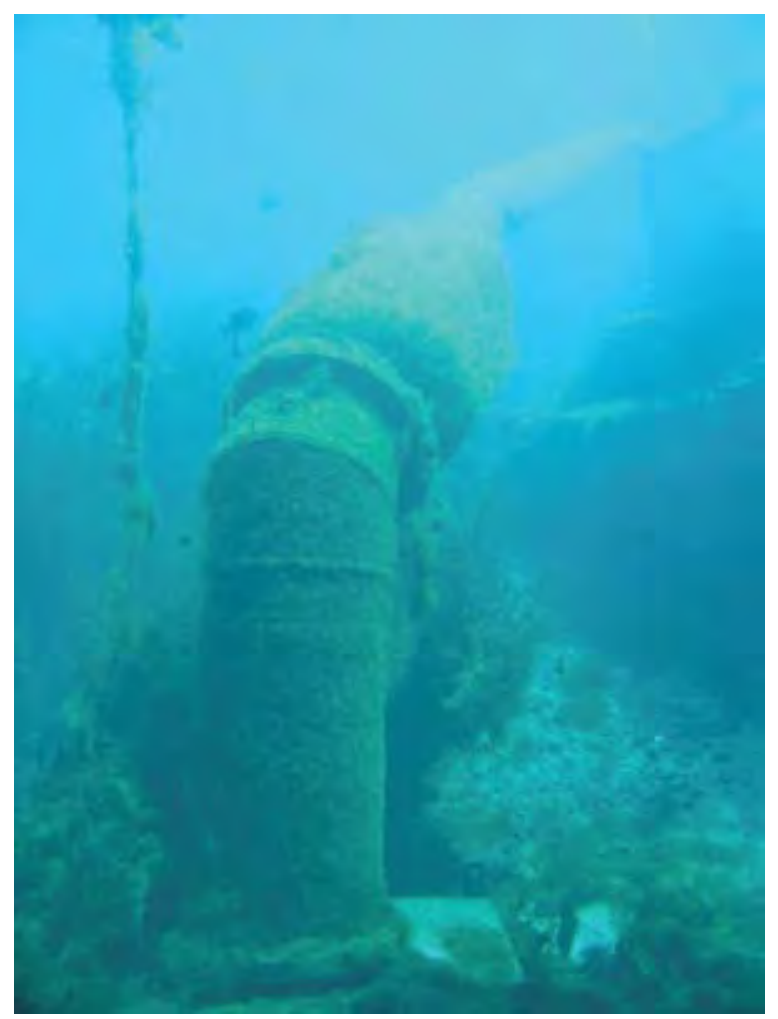

Figure 14. Biota net installed on steel pipe structure at diversion spring at San Marcos Springs.

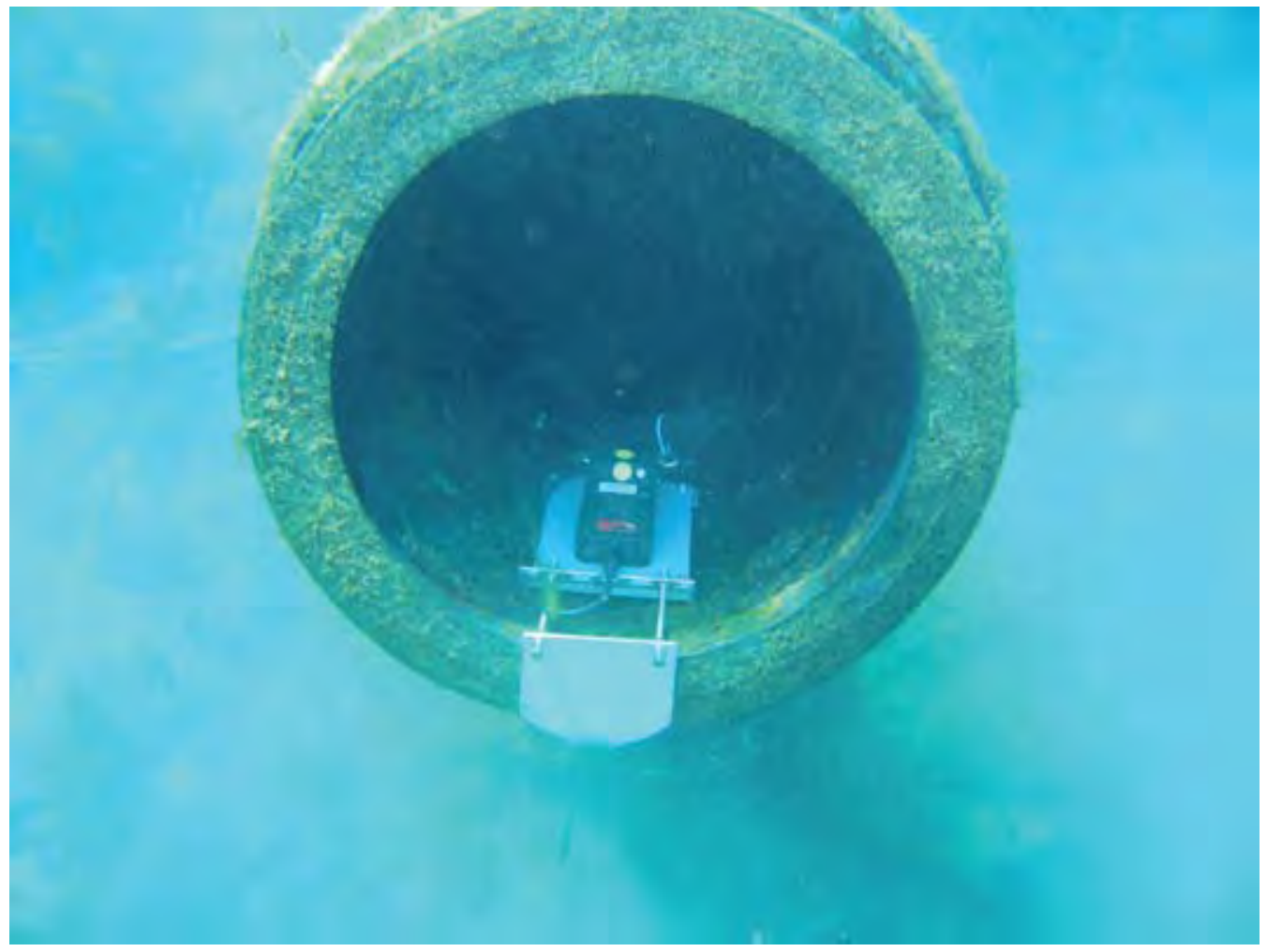

Figure 15. Argonaut SW installed inside steel pipe over diversion spring at San Marcos Springs. 


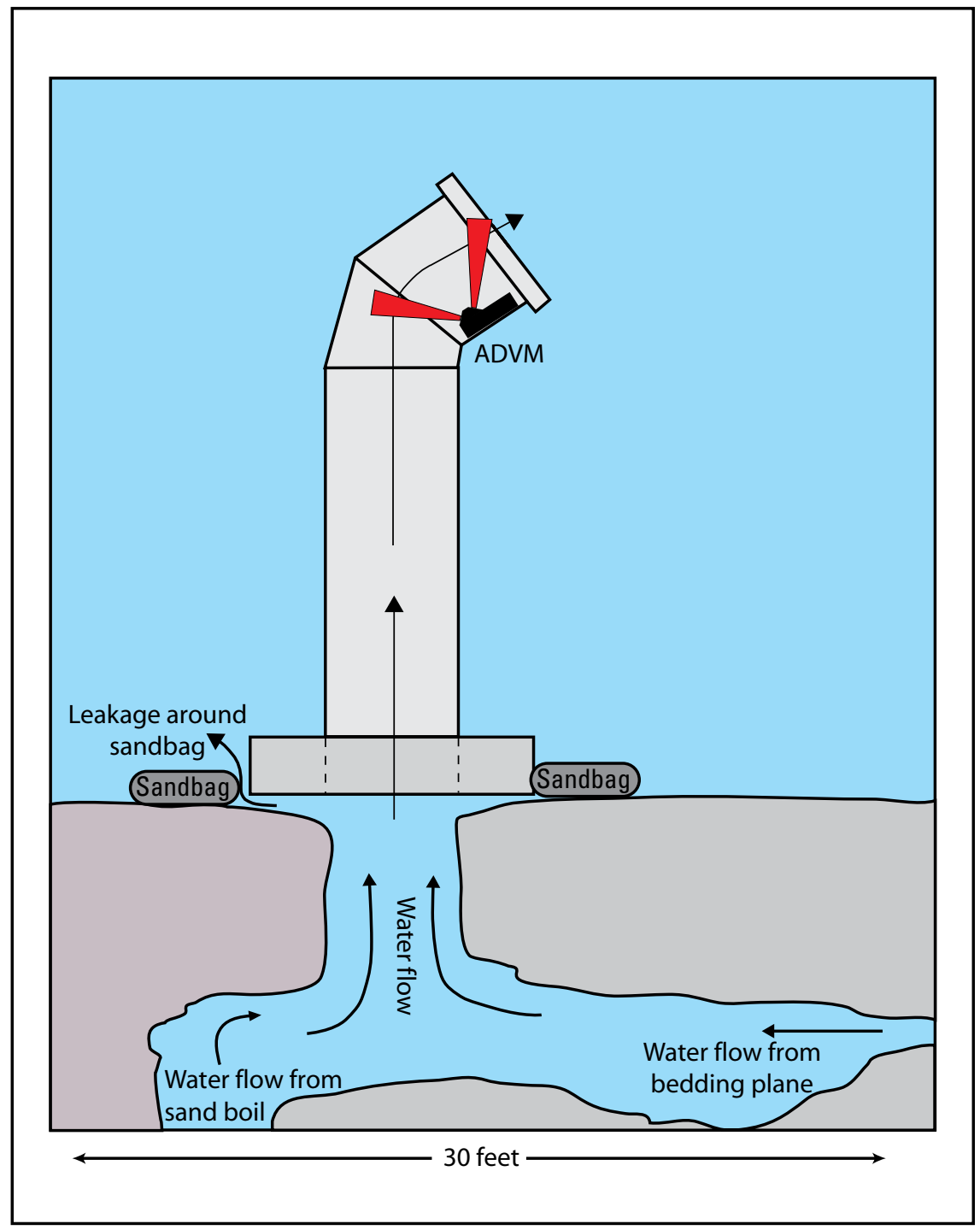

Not to scale

Figure 16. Schematic showing diversion spring cave at San Marcos Springs, pipe assembly covering spring, and location of acoustic Doppler velocity meter (ADVM) inside pipe

\section{San Marcos Springs-San Marcos River Streamflow Gage}

The streamflow-gaging station 08170500 San Marcos River at San Marcos has operated continually since 1995 and is the primary source of real-time flow data from San Marcos Springs. Station 08170500 is on Aquarena Springs Drive bridge, and a standard stage-discharge rating is used to compute continuous discharge. The streambed is gravel and cobbles with periodically dense vegetation including Texas wild rice. Channel width at the gage is 86 feet. An Argonaut SW was installed in the primary flow channel of the river and attached to a bridge pier using a custom clamp-on bracket (no bolts drilled into pier). The ADVM bracket extends laterally 4 feet from the pier so that the ADVM is a sufficient distance from the pier to avoid excessive turbulent flow around the pier (figs. 20,21). Placement of the ADVM was limited to the immediate vicinity of the pier to address the safety of swimmers, as the gage location is in a public park. The $\mathrm{x}$ and $\mathrm{y}$ velocity components are measured and resultant velocity magnitude is computed. The instrument collects data in 15-minute intervals using a 300-second (5-minute) averaging interval. The data are logged in the station DCP that transmits real-time data from the site. 


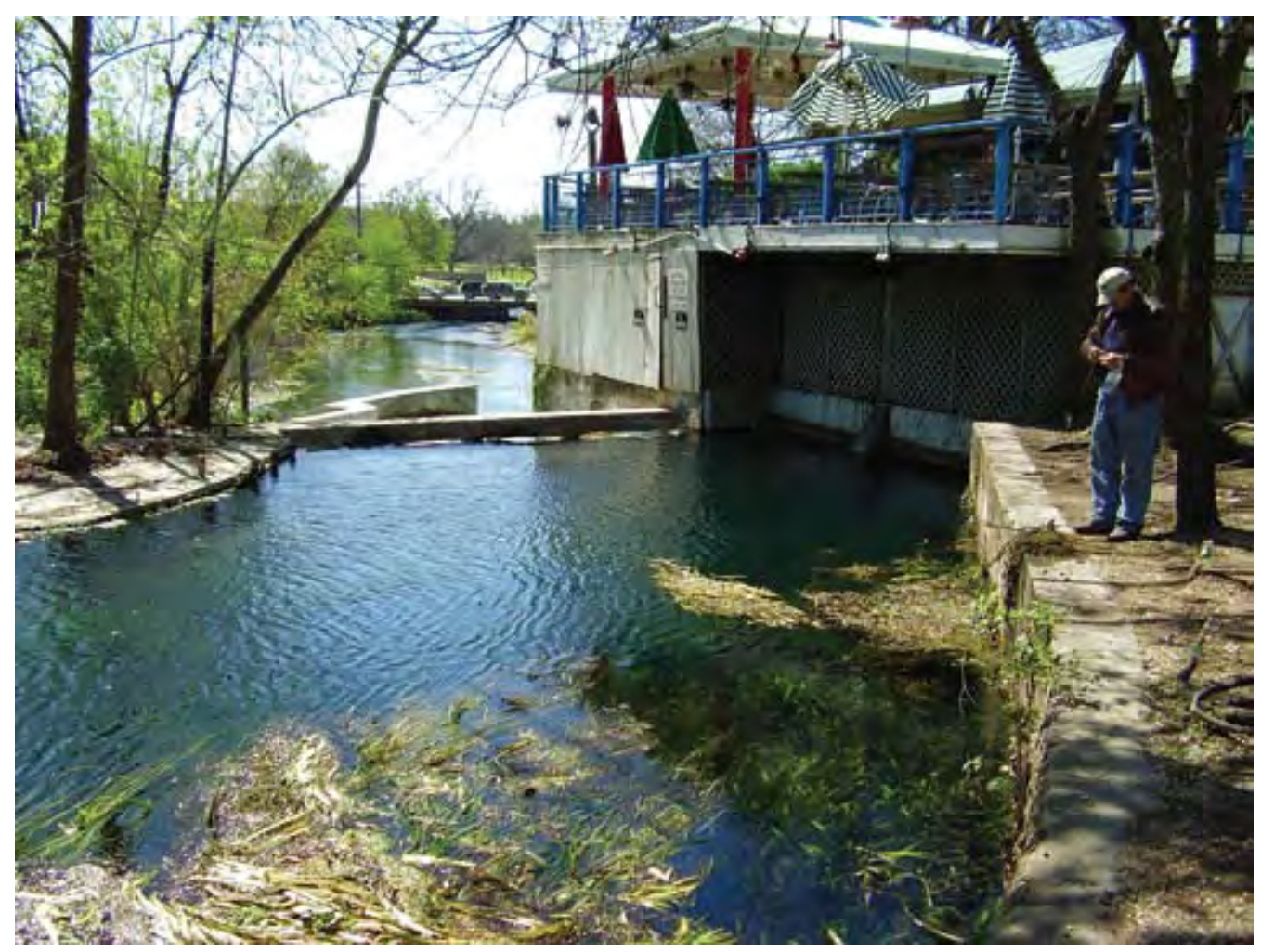

Figure 17. View looking downstream from west outflow channel of Spring Lake, San Marcos. Four gates seen on dam between concrete columns, and Federally listed endangered species, Texas wild rice, seen in foreground.

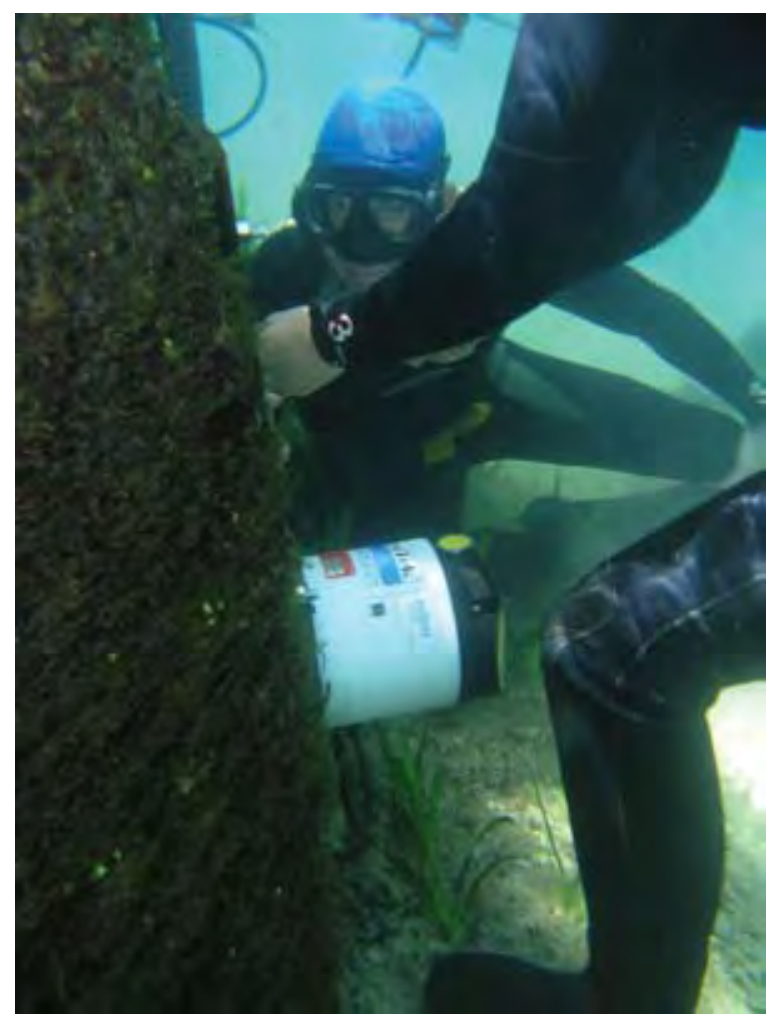

Figure 18. U.S. Geological Survey divers installing Argonaut SL on left bank of west outflow channel of Spring Lake, San Marcos. 


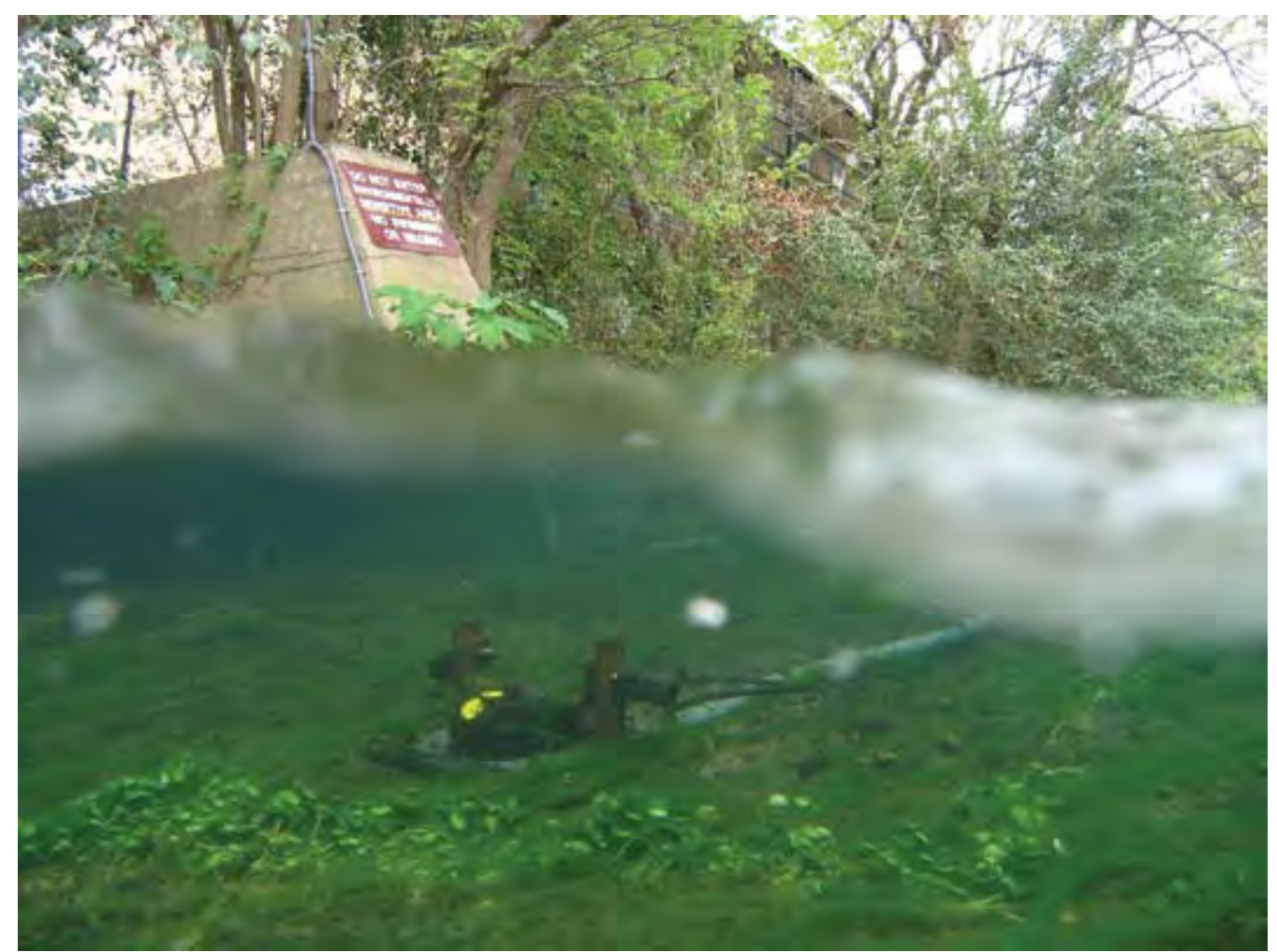

Figure 19. Argonaut SW installed in east outflow channel of Spring Lake, San Marcos.

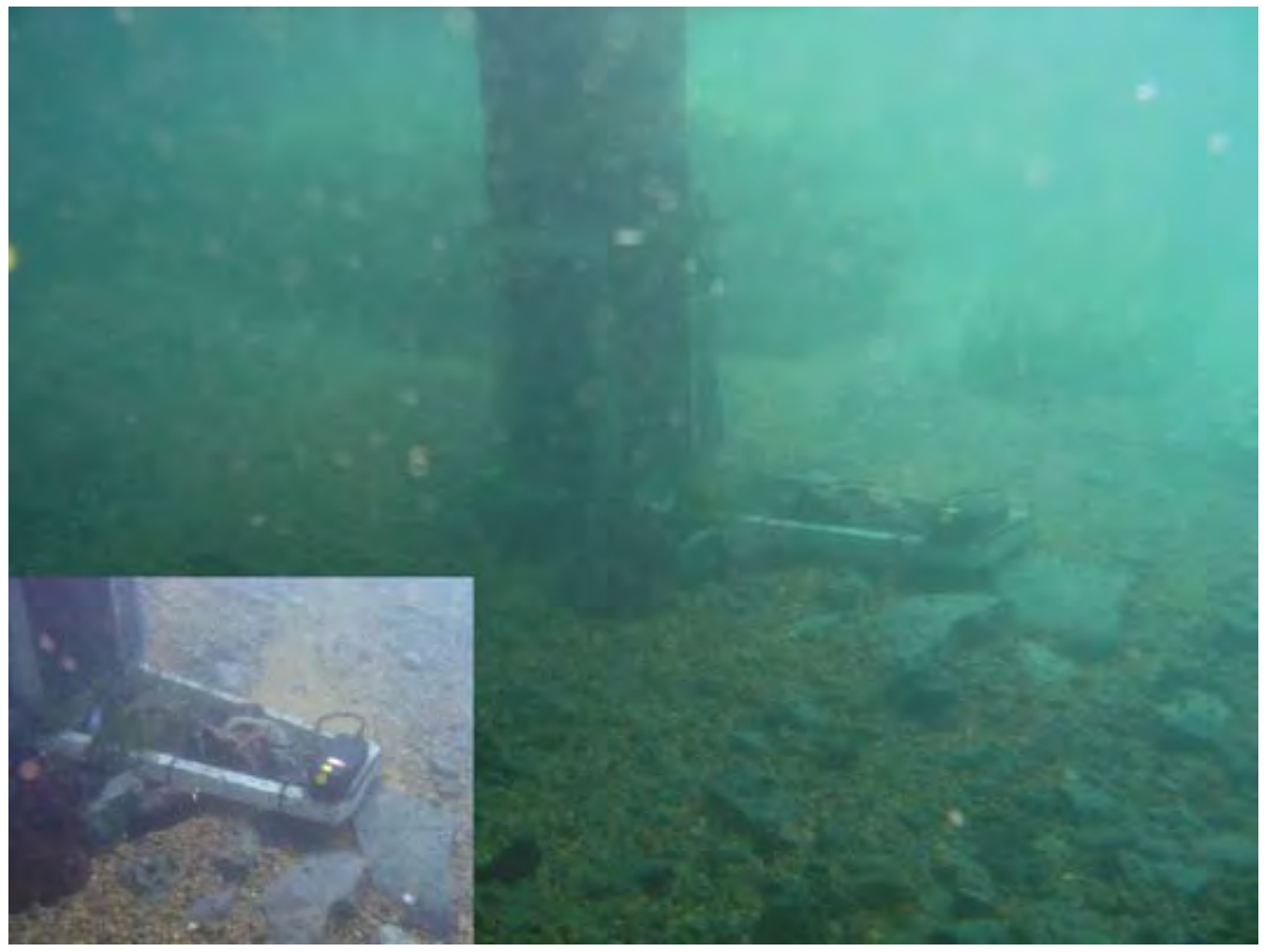

Figure 20. Argonaut SW installed at station 08170500 San Marcos River at San Marcos attached to bridge pier in primary channel of flow. Inset shows close-up of instrument. 

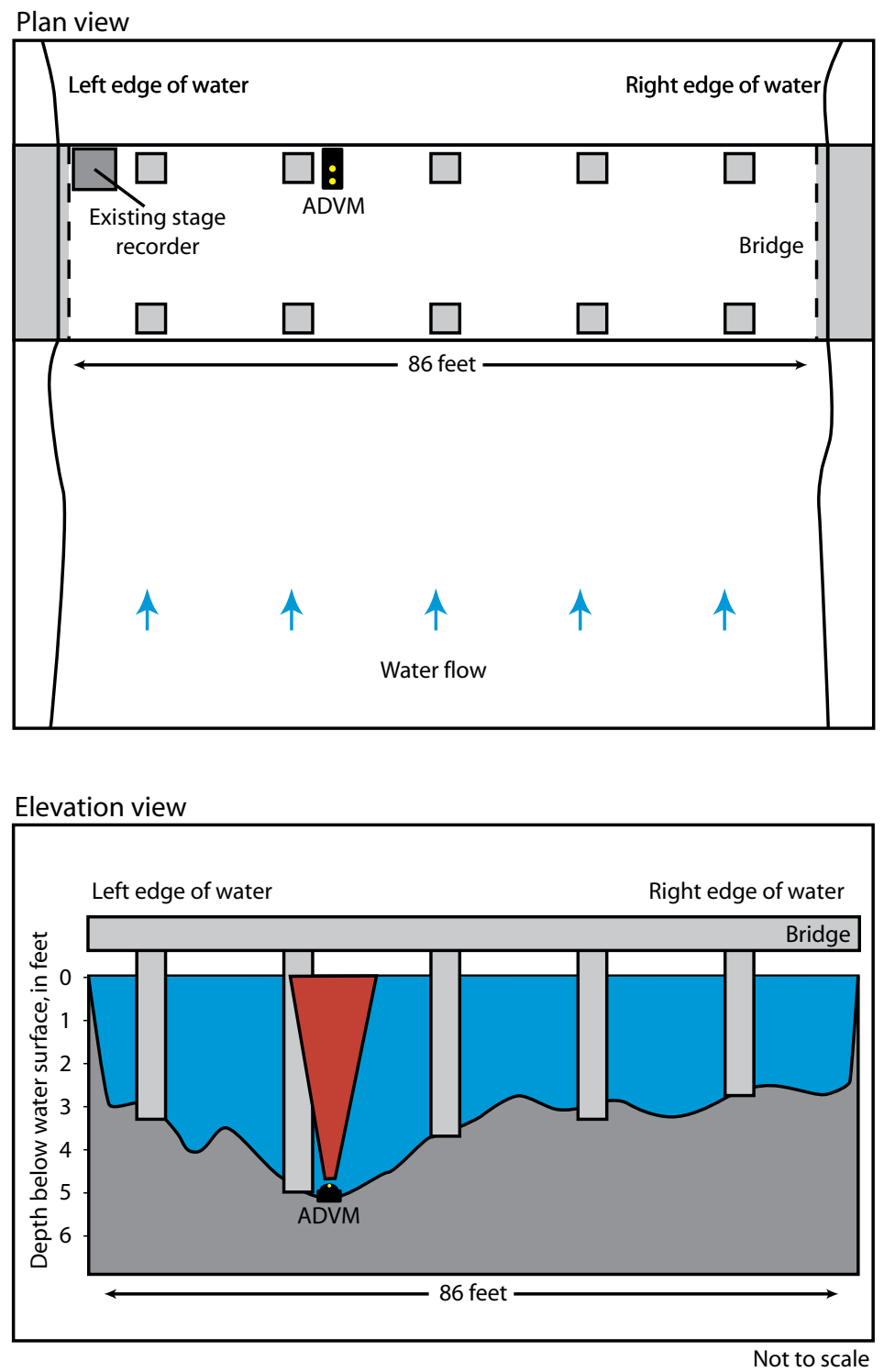

Figure 21. Schematic showing location of acoustic Doppler velocity meter (ADVM) next to bridge pier at station 08170500 San Marcos River at San Marcos.

\section{Data Quality Assurance and Archival}

Data collected from ADVMs were checked for outliers and anomalous and missing data on a monthly or more frequent basis during the study. ADVMs connected to a DCP transmitted measurements to the USGS NWIS database (U.S. Geological Survey, 2008). The ADVM data in NWIS were checked each week to ensure that accurate velocity data were being recorded. ADVMs programmed to record measurements internally were serviced and data were downloaded every few weeks and manually uploaded into NWIS. All data for each of the eight ADVM monitoring stations were quality checked, analyzed, and archived in NWIS. For convenience, select ADVM data from this study also are included in appendix 1 (figs. 1.1, 1.2) of this report.

\section{Evaluation of Acoustic Doppler Velocity Meters to Quantify Flow}

Data were collected for eight ADVM monitoring sites during May 2006 through September 2007, although all eight sites were not operational concurrently throughout the entire 17-month period. As data were collected and 
reviewed, the data also were evaluated with regard to several criteria to indicate whether results for each site met the overall objectives of the study to improve methods of flow measurement and thus estimates of total springflow for Comal and San Marcos Springs. The evaluation criteria were: (1) The ADVM was capable of collecting accurate data, even in clear spring water with few particles to generate an acoustic signal return. (2) The environmental conditions (vegetation) at the site had little or no effect on velocity measurements.

(3) The site provided consistent velocity data directly reflective of the environment with little or no influence from anthropogenic changes to the physical flow system. If anthropogenic effects exist, were they directly quantifiable? (4) Velocity data from a specific site had sufficient resolution relative to total springflow fluctuations to provide a reasonable index to quantify total instantaneous springflow. (5) The datacollection techniques can be associated with standard, published methods to generate an official discharge record for the site.

\section{Comal Springs—Spring Run 3}

ADVM application at this site was intended to indicate whether the flow of spring run 3 could be related to total springflow. LBG Guyton Associates (2004) reported that flow measured in spring run 3 represented 13 percent of total Comal Springs flow as indicated by streamflow recorded at station 08169000 Comal River River at New Braunfels in each of three measurements made. Data were collected from the ADVM from June 2006 through early March 2007 (fig. 22). The velocity record shows the highest shift in the data resulted from a change in the stream geometry in July 2006. A rock dam immediately downstream from the ADVM was created by unknown persons, raising the water level 0.2 foot and thus dropping the velocity by about 30 percent; however, no similar decrease in total springflow (as measured at station 08169000) occurred then. The data show subtle patterns of variation in velocity that can be distinguished from the pattern of streamflow at station 08169000-for example, in November 2006 when two decreases in stream velocity of about 10 percent occurred, although no change in streamflow at the gage was observed.

The velocity data collected by the ADVM during January 2007 do not correlate with the hydrograph of streamflow from station 08169000 (fig. 23). The ADVM measured about a 20-percent increase in stream velocity in spring run 3 on January 10 with no subsequent recession; no increase in streamflow was recorded at station 08169000 on that day. An increase in flow of about 300 cubic feet per second was recorded 3 days later at station 08169000 , but no corresponding response in velocity is indicated by the ADVM data at spring run 3. Two subsequent smaller peaks in flow were recorded at the gage on January 15 and 24, but again no corresponding response in velocity is indicated by the ADVM data at spring run 3. Velocity data from spring run 3 indicate changes in flow in this discharge feature, but the data do not reliably show a direct relation to total Comal Springs flow, assuming that total springflow is indicated by streamflow at station 08169000.

\section{Comal Springs-Spring 7}

As at spring run 3, the ADVM application at spring 7 was intended to indicate whether the flow computed from velocity data recorded at this discrete discharge point could be related to total springflow for Comal Springs. The velocity data record from spring 7 extends from July 2006 through April 2007 (fig. 24). An initial concern regarding collecting ADVM data at this site was that water flowing from this orifice is exceptionally clear, and the acoustic signal strength might be too low to measure accurate velocities. Although the data noise (variation) is about 25 percent of measured velocities, distinct temporal patterns in the record are observable. The velocity data generally track with streamflow data recorded at station 08169000, particularly during summer 2006, a period of negligible base flow when streamflow represented essentially all springflow. However, an unexplained sharp increase in velocity (about 38 percent) followed closely by a sharp decrease (about 92 percent) occurred in mid-November 2006 (fig. 25). No corresponding change in streamflow was recorded at station 08169000. During the later part of the record (2007), the orifice velocity data and streamflow data likely show the influence of more storms than in the early part of the record, and the relation between the two time series becomes difficult to resolve. The velocity data in spring 2007 show intense fluctuations and the streamflow data show several large spikes in flow, but the changes in the two time series do not appear to be closely related (fig. 26). As with data from spring run 3, data from spring 7 do not reliably show a direct relation to streamflow at station 08169000, and thus to total Comal Springs flow, assuming that total springflow is indicated by streamflow at station 08169000.

\section{Comal Springs-New Channel}

The ADVM installed in the new channel of the Comal River operated from June through September 2007 (fig. 27). The new channel site has several advantages with regard to ADVM use: (1) The weir provides a stable control that can be rated easily, particularly when an ADVM is deployed. Standard discharge rating using velocity-stage-index methods described by Morlock and others (2002) can be applied to quantify flow over the weir. (2) The bypass valve can be closed, allowing for all water to flow over the weir. When the bypass valve is open, flow in the bypass pipe can be quantified by the second ADVM in the pipe. (3) The new channel gaging site is considerably closer to Landa Lake than station 08169000, which reduces the 


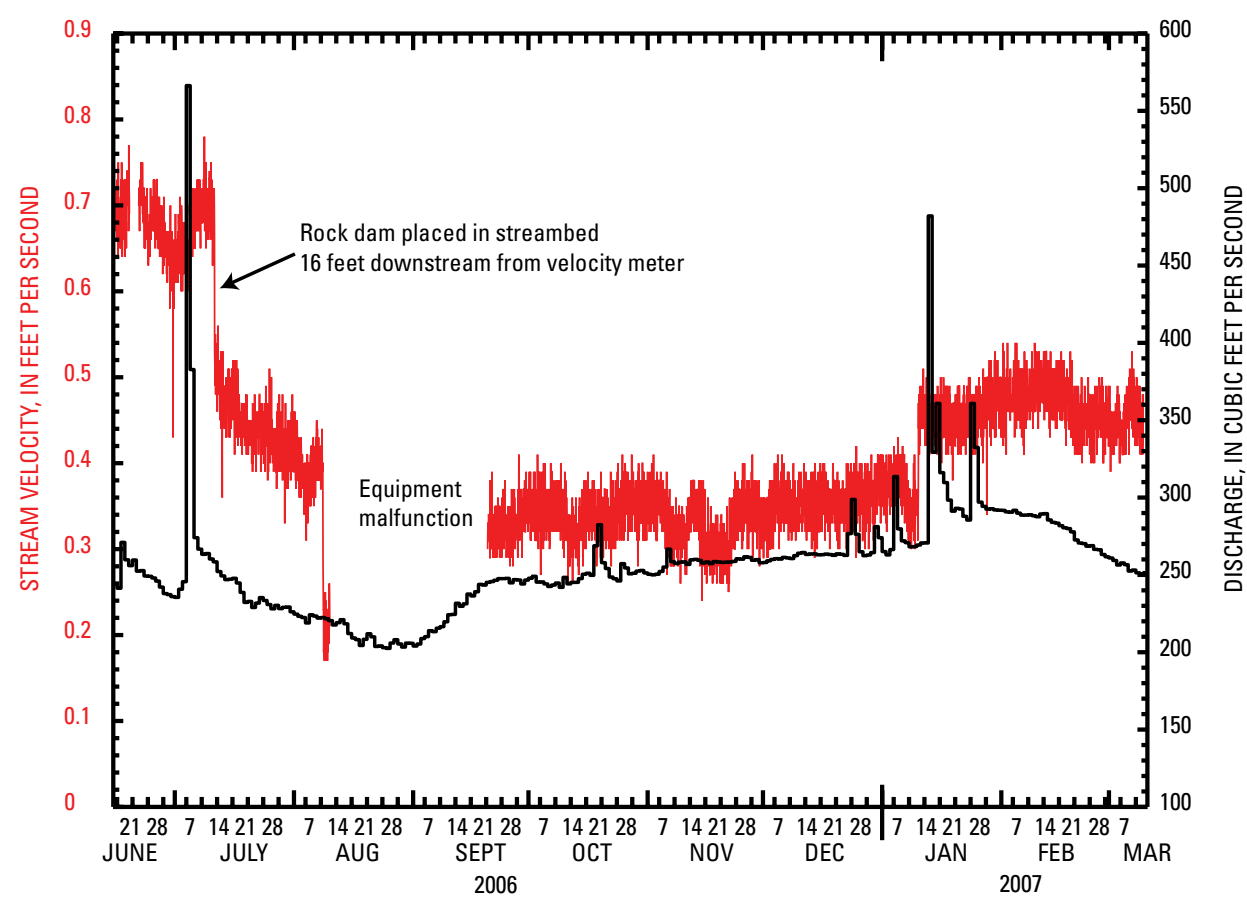

EXPLANATION

— Instantaneous stream velocity from spring run 3, site 294250098080900 (DX-68-23-321)

— Instantaneous daily mean discharge from Comal River at New Braunfels, site 08169000

Figure 22. Velocity magnitude from spring run 3 at Comal Springs and streamflow from station 08169000 Comal River at New Braunfels during acoustic Doppler velocity meter deployment.

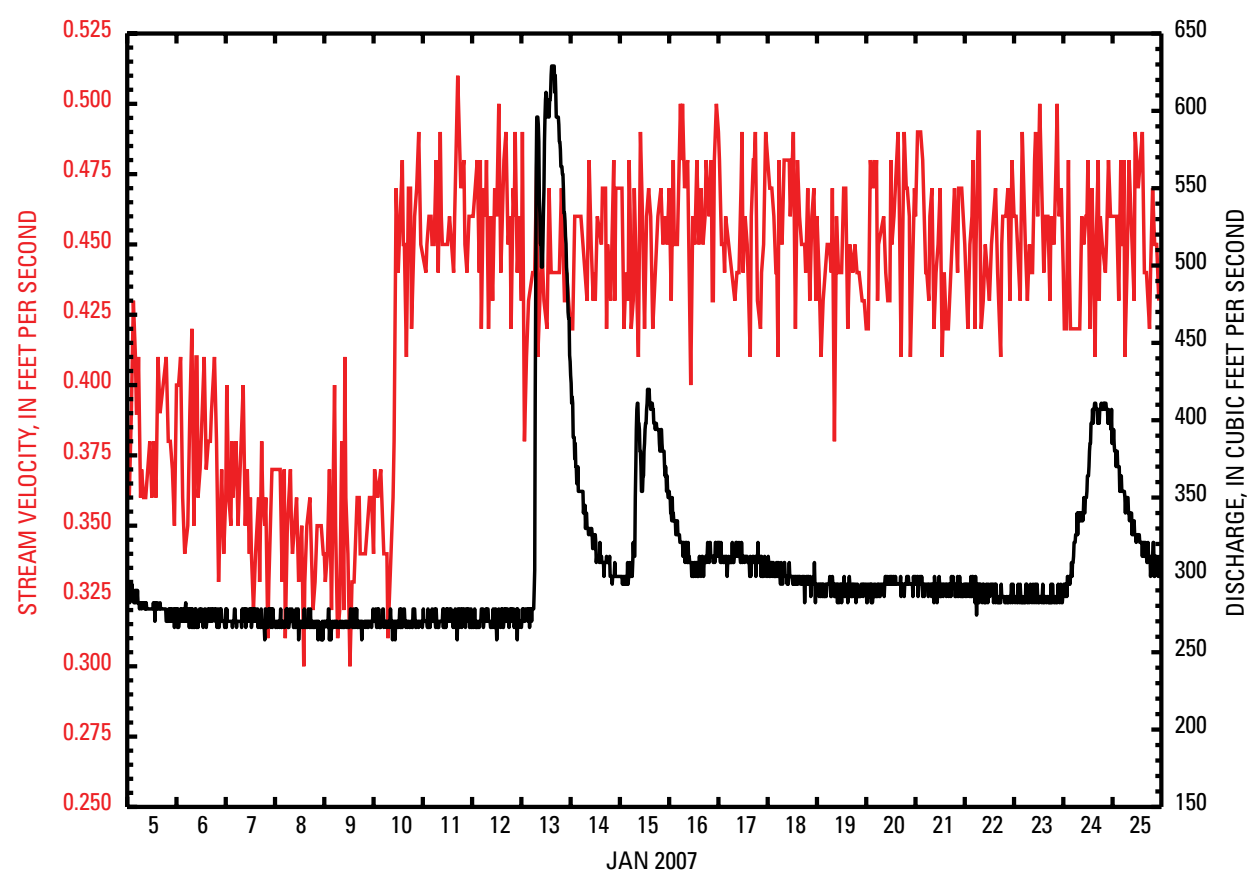

\section{EXPLANATION}

- Instantaneous stream velocity from spring run 3, site 294250098080900 (DX-68-23-321)

— Instantaneous discharge from Comal River at New Braunfels, site 08169000

Figure 23. Velocity magnitude from spring run 3 at Comal Springs and streamflow from station 08169000 Comal River at New Braunfels, January 2007. 


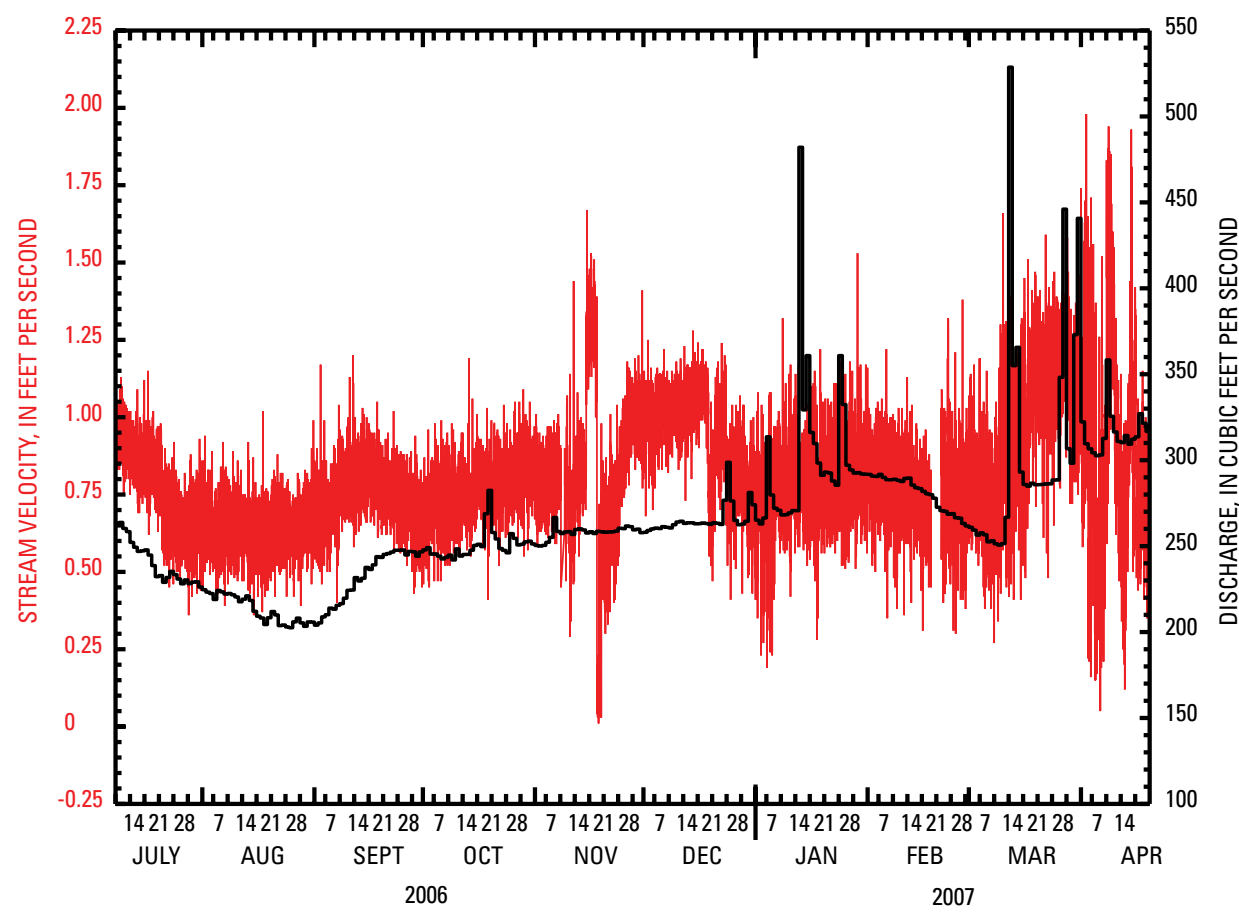

EXPLANATION

- Instantaneous stream velocity from spring 7, site 294255098080501 (DX-68-23-324)

— Instantaneous daily mean discharge from Comal River at New Braunfels, site 08169000

Figure 24. Velocity magnitude from spring 7 at Comal Springs and streamflow from station 08169000 Comal River at New Braunfels during acoustic Doppler velocity meter deployment.

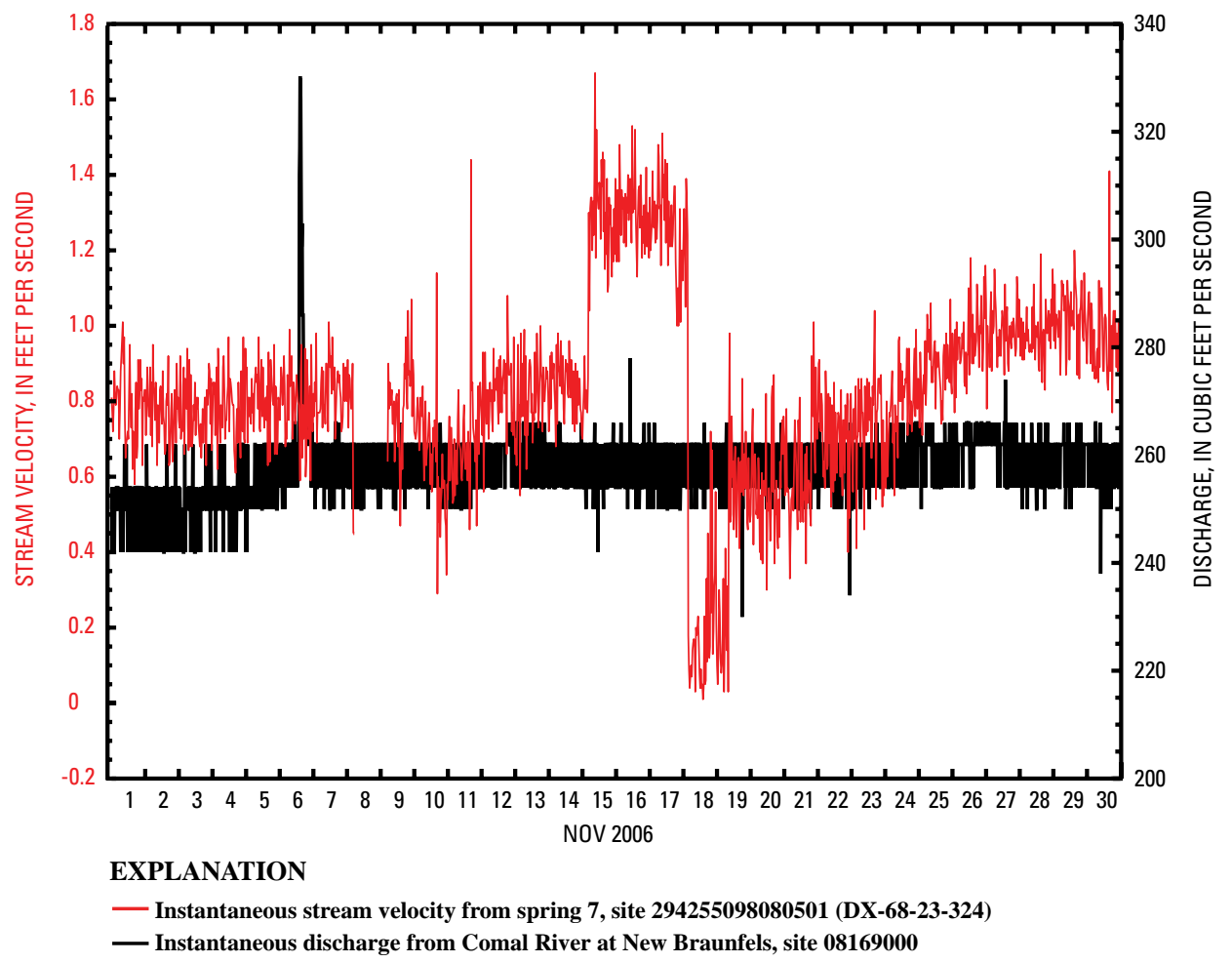

Figure 25. Velocity magnitude from spring 7 at Comal Springs and streamflow from station 08169000 Comal River at New Braunfels, November 2006. 


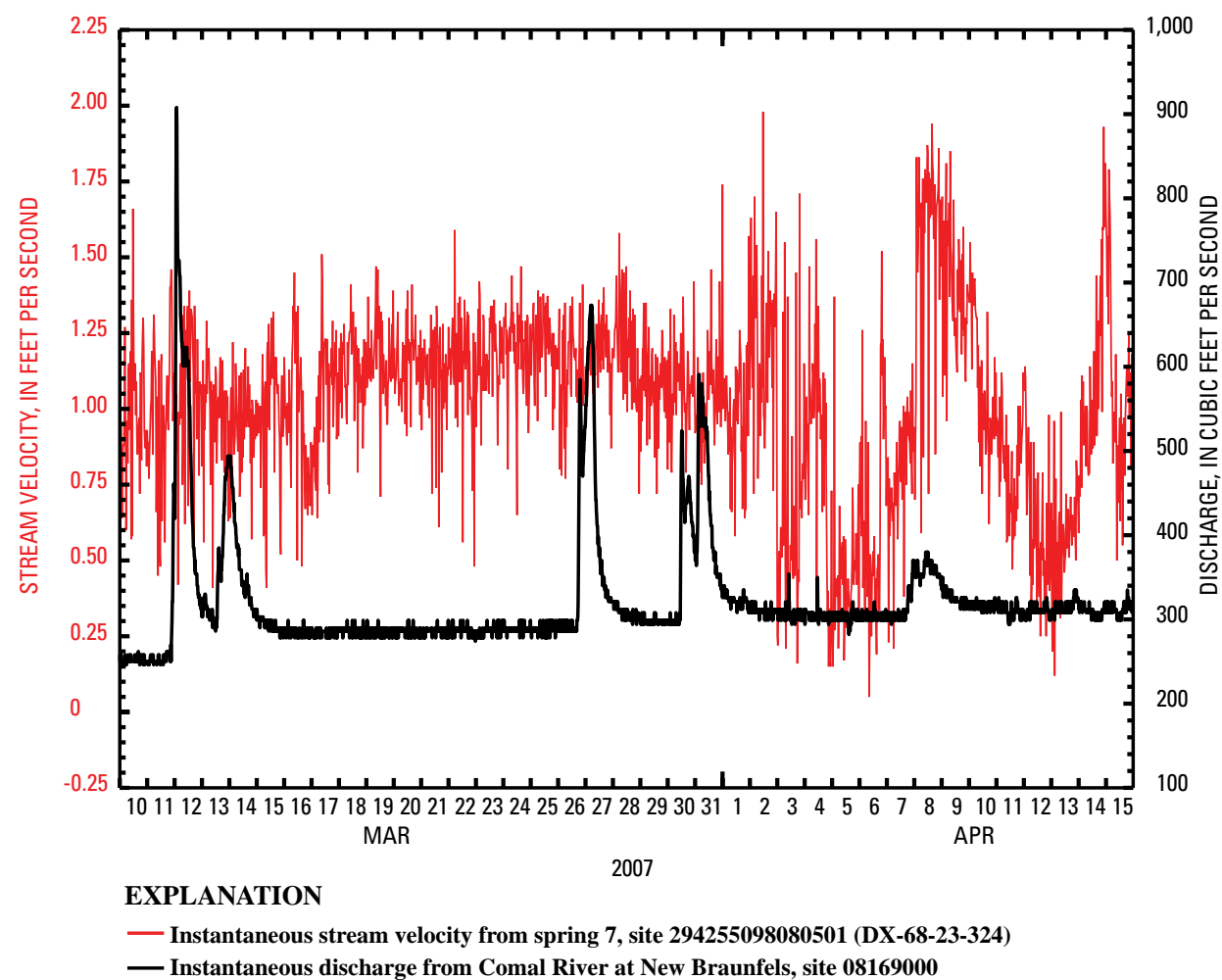

Figure 26. Velocity magnitude from spring 7 at Comal Springs and streamflow from station 08169000 Comal River at New Braunfels, March-April 2007.

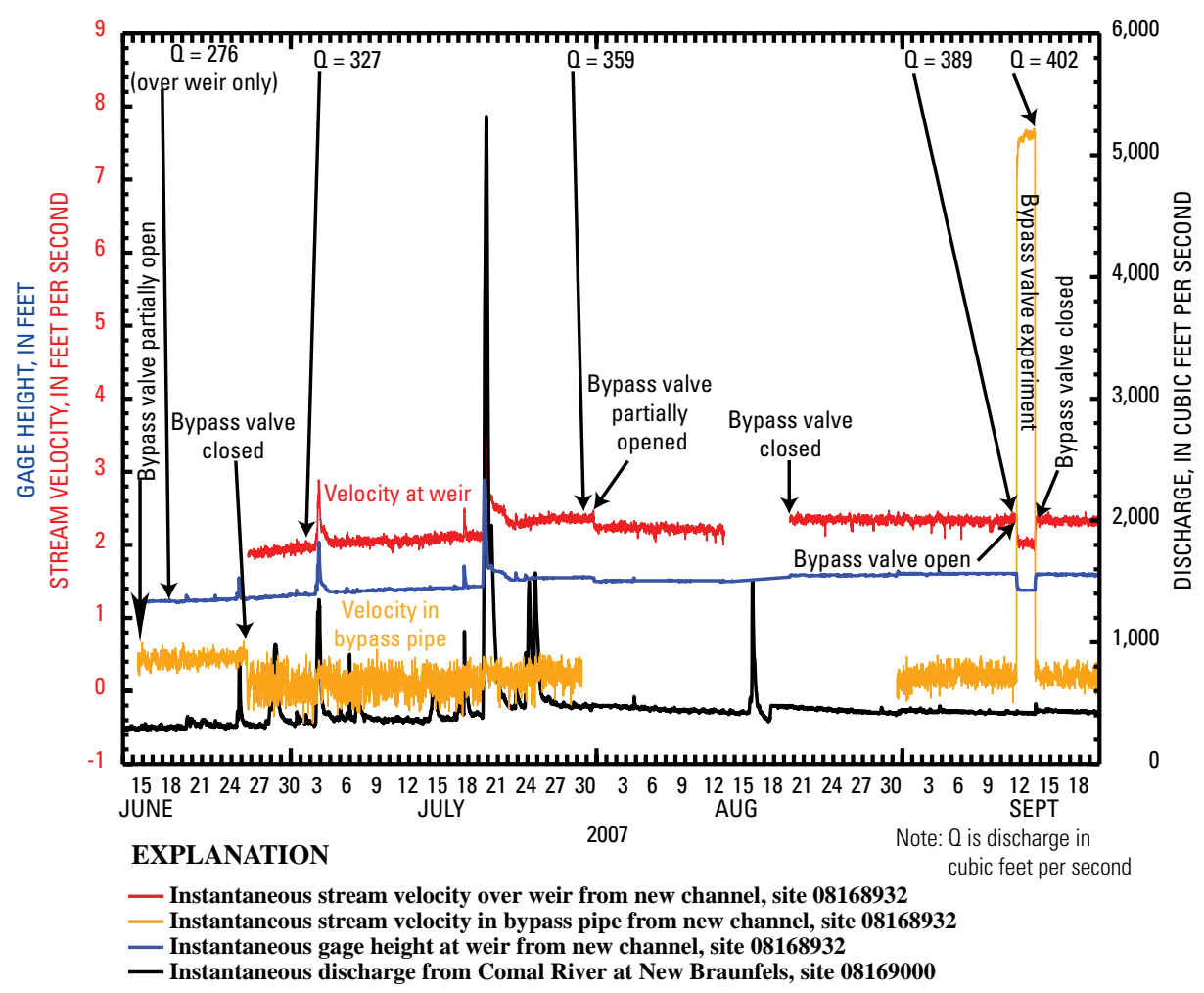

Figure 27. Velocity magnitude over weir and in bypass pipe from new channel of Comal River; gage height at weir from new channel of Comal River; and streamflow from station 08169000 Comal River at New Braunfels during acoustic Doppler velocity meter deployment. 
length of stream reach subject to streamflow gains and losses that lessen the reliability of gaged streamflow at station 08169000 as the indicator of real-time total springflow. (4) The site is secure in that it is not easily accessed by the public, which lessens the potential for vandalism.

Velocity data from the two ADVMs, when used in tandem, provide excellent stage and velocity data that can be used to produce an accurate discharge rating at this site. With both instruments deployed on June 26, 2007, the bypass valve was completely closed, and velocity data values from the ADVM in the bypass pipe fluctuated \pm 0.3 foot per second (fig. 27), which indicates only turbulent, circular water movement. With the valve partially open, water velocity in the pipe was stable and averaged 0.4 foot per second. The observable difference in recorded velocity data between the valve-open and valve-closed periods indicates that the ADVM can be used to reliably determine whether the valve is open or closed, and if open, the flow can be directly quantified.

A flow experiment was conducted September 12-14, 2007, to evaluate the variation in flow over the weir and through the bypass pipe (fig. 28). With the valve completely closed and all water flowing over the weir before September 12, the measured flow over the weir was 389 cubic feet per second. After complete opening of the bypass valve, water velocity in the pipe increased from about 0 to about 7.6 feet per second, the gage height (stage) at the weir decreased 0.23 foot, and the velocity of flow over the weir decreased about 0.3 foot per second. Flow conditions were allowed to stabilize for 2 days, and then discharge over the weir was directly measured at 334 cubic feet per second. Flow in the pipe was computed to be 68 cubic feet per second using pipe-flow hydraulics (appendix 1, fig. 1.3). The bypass valve was then completely closed, and flow conditions returned to essentially those before the experiment. A slight decrease in gage height was observed, which could be a result of loss of storage in Landa Lake that occurred because the bypass valve was open for 2 days. The data indicate flow at the weir during the experiment increased from 389 to 402 cubic feet per second (334 cubic feet per second over the weir plus [estimated] 68 cubic feet per second through the pipe); however, the difference of 13 cubic feet per second is within the acceptable error of USGS flow measurement and estimation.

The velocity and gage-height records from the new channel site provided a good indication that springflow could be discriminated from surface-water inflows downstream from this site and upstream from station 08169000. Streamflow response during June 28-29, 2007, to a local rain event was recorded by the Comal River gage, but no corresponding response in velocity or gage height was recorded by the ADVM at the new channel site (fig. 29). The findings for the new channel site indicate that ADVM use there could potentially contribute to increased accuracy of real-time springflow estimates.

\section{Comal Springs - Old Channel}

To quantify total springflow from Comal Springs, both outflow channels (new channel and old channel) must be gaged. The gaging site on the old channel is not as well suited for measuring flow as the site on the new channel, but data of acceptable accuracy can be collected at the old channel site. Data were collected from June through September 2007 (fig. 30). Recorded data at this site varied with frequent (generally weekly) changes in flow associated with upstream pool maintenance in summer. Sharp peaks in velocity and gage height were recorded as the pool was rapidly drained, then decreases in velocity and gage height were recorded as the pool was refilled.

Data recorded at the site during July 20-August 20, 2007 (fig. 31) reflect a series of rises that covered the ADVM with debris and obstructed flow through the culverts immediately downstream. Velocities in general were low during this period, as outflow from the swimming pool was reduced.

With velocity and stage data collected and applied to a velocity-stage discharge rating for the old channel site, it is possible to continuously gage the flow at the site. Without velocity data, stage data alone would not be adequate to quantify flow when debris obstructs the downstream culverts. However, when clear, the culverts maintain stable water levels and provide a control structure that produces uniform flow over the ADVM. The findings for the old channel site indicate that ADVM use there, assuming concurrent ADVM use at the new channel site, could potentially contribute to increased accuracy of real-time springflow estimates.

\section{San Marcos Springs-Diversion Spring}

Initially, diversion spring with its 26-inch diameter pipe appeared to be a promising site to index the discharge of San Marcos Springs. An ADVM was installed and data were collected during May through September 2006. Data show that when the biota net is installed on the pipe, water velocity in the pipe decreases $25-30$ percent (fig. 32). The net was installed on May 16 and removed on May 19; then on June 1 , the net was replaced for the remainder of the study. The authors believe that the decrease in velocity is a result of back pressure exerted by the net, and the flow lost out of the pipe is diverted to leakage around the base structure (fig. 16). Although the general trend of velocity correlates well with flow measured at station 08170500 , the uncertainty associated with the biota net installation and its influence on velocity measurements in the pipe make this site less desirable for accurately indexing the total flow of San Marcos Springs.

\section{San Marcos Springs-West Outflow}

Of the two outflow channels at Spring Lake, discharge at the west site is twice the volume on average of discharge at the 


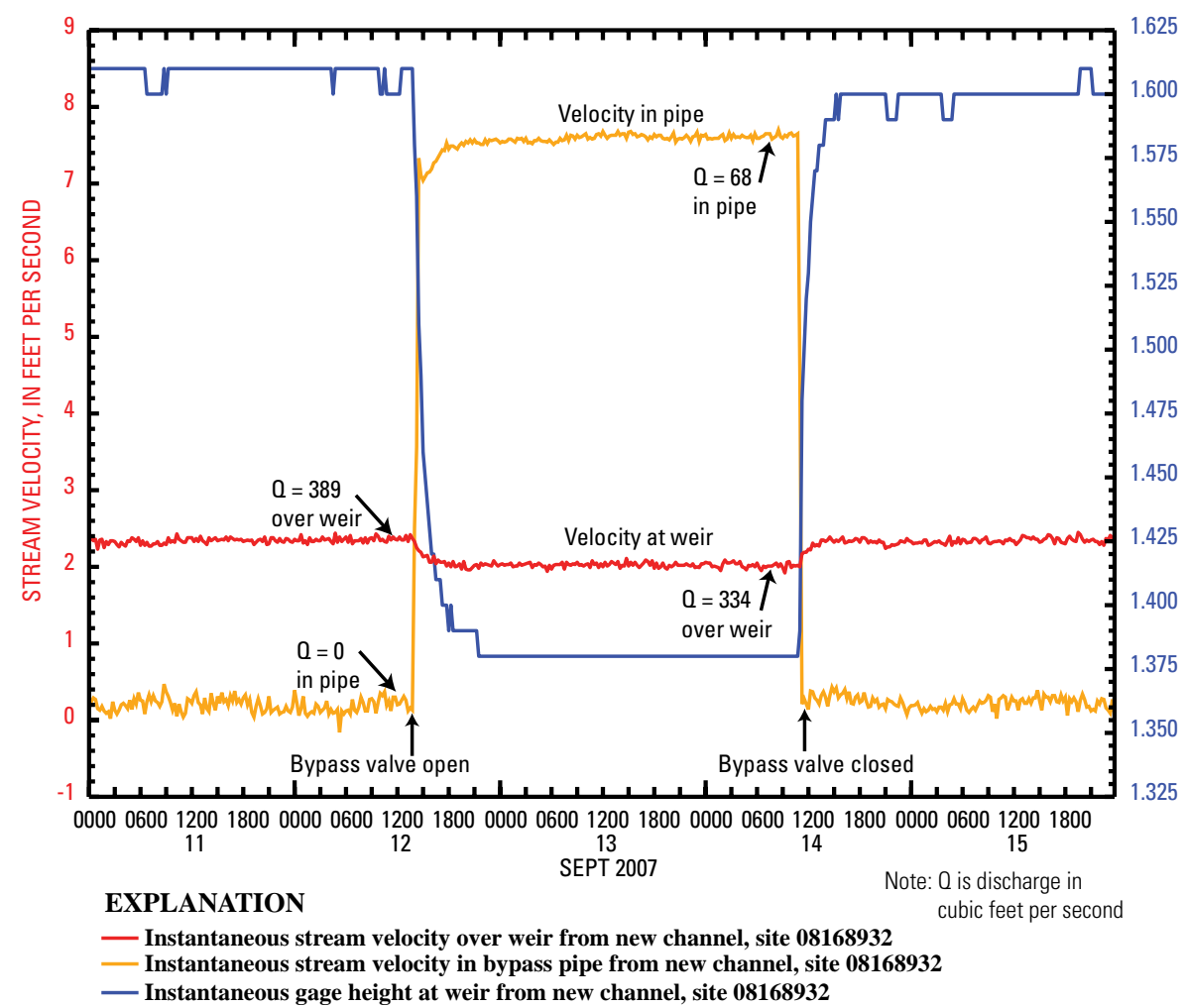

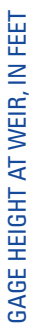

Figure 28. Velocity magnitude over weir and in bypass pipe from new channel of Comal River, and gage height at weir from new channel of Comal River during bypass valve experiment.

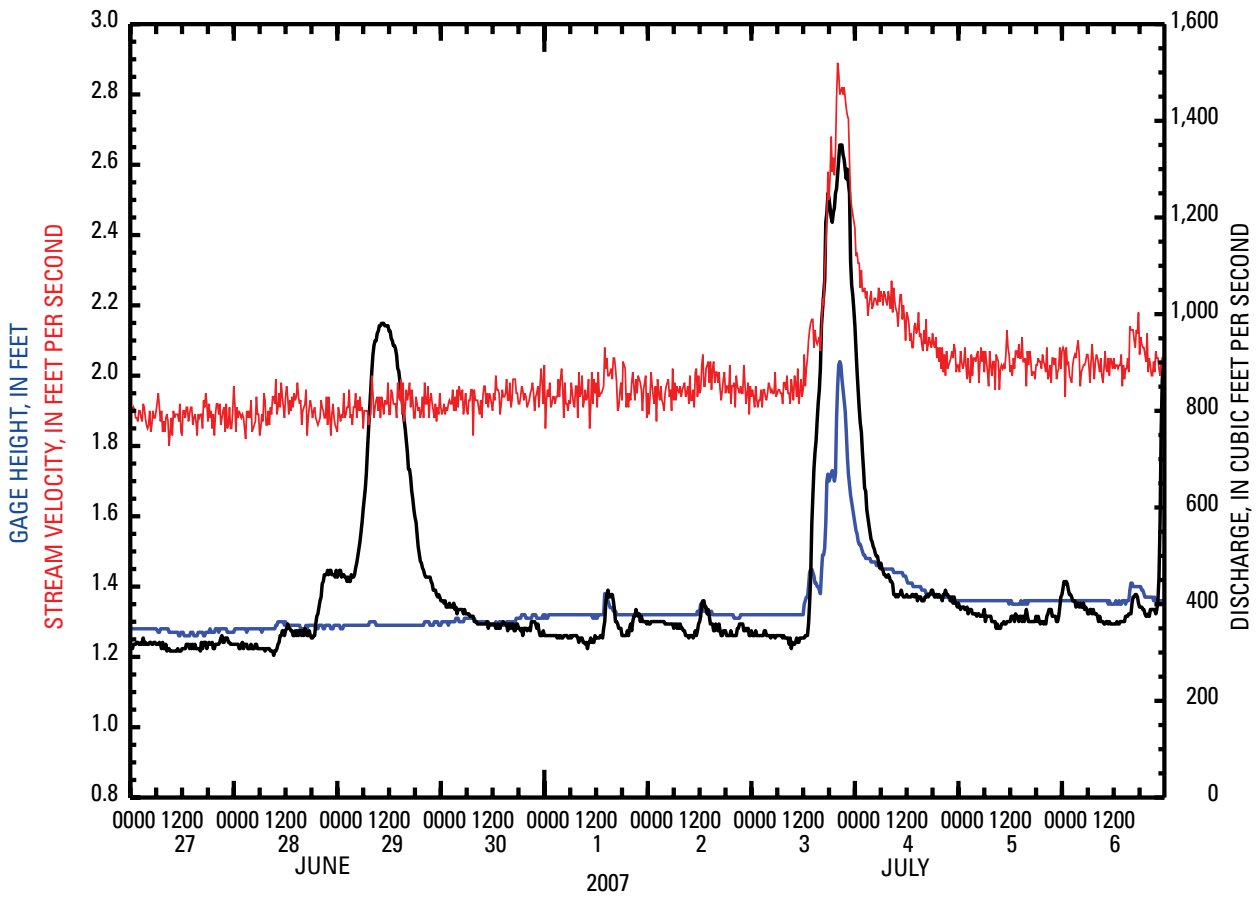

EXPLANATION

— Instantaneous stream velocity over weir from new channel, site $\mathbf{0 8 1 6 8 9 3 2}$

- Instantaneous gage height at weir from new channel, site $\mathbf{0 8 1 6 8 9 3 2}$

- Instantaneous discharge from Comal River at New Braunfels, site 08169000

Figure 29. Velocity magnitude over weir from new channel of Comal River; gage height at weir from new channel of Comal River; and streamflow from station 08169000 Comal River at New Braunfels, June-July 2007. 


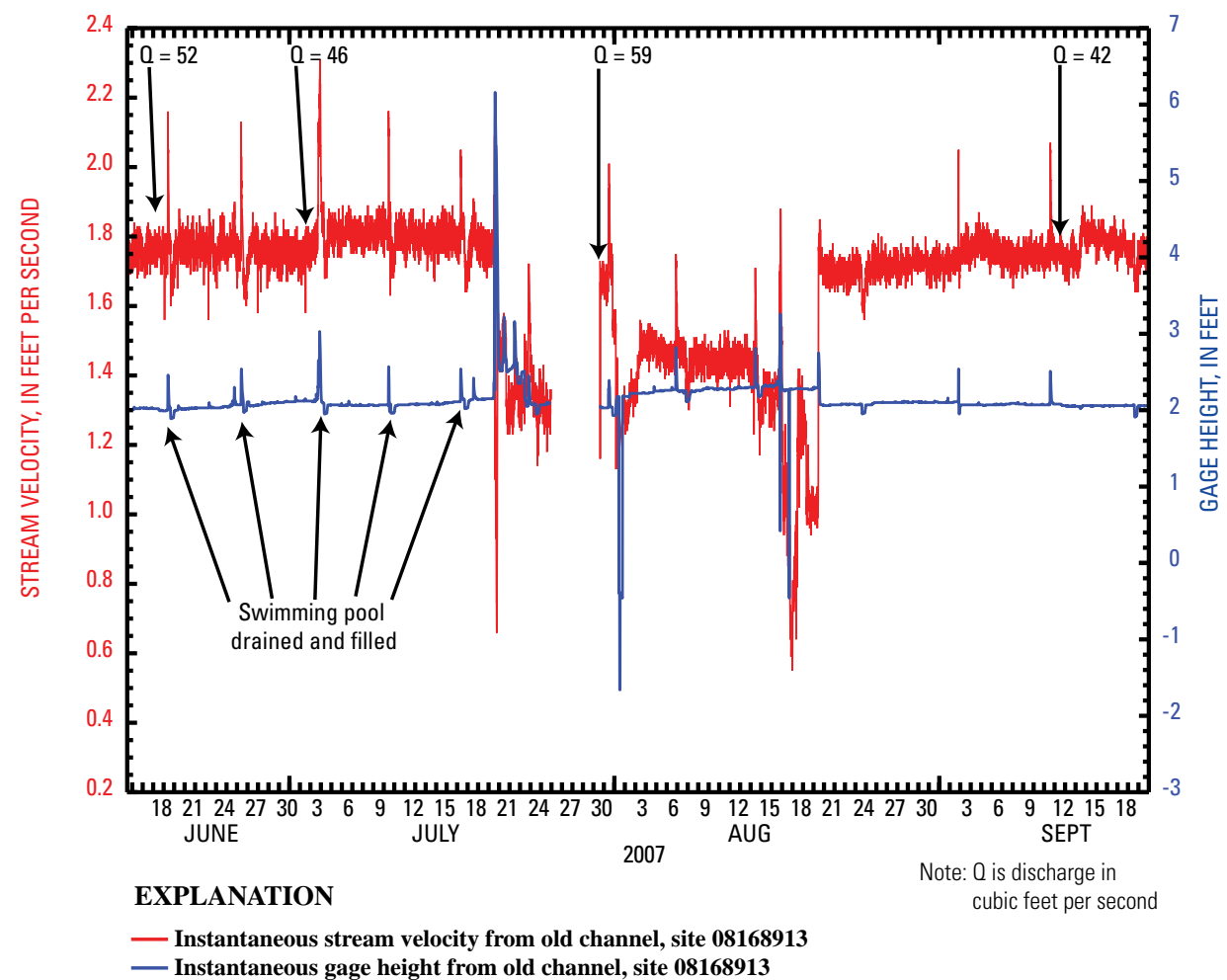

Figure 30. Velocity magnitude and gage height from old channel of Comal River during acoustic Doppler velocity meter deployment.

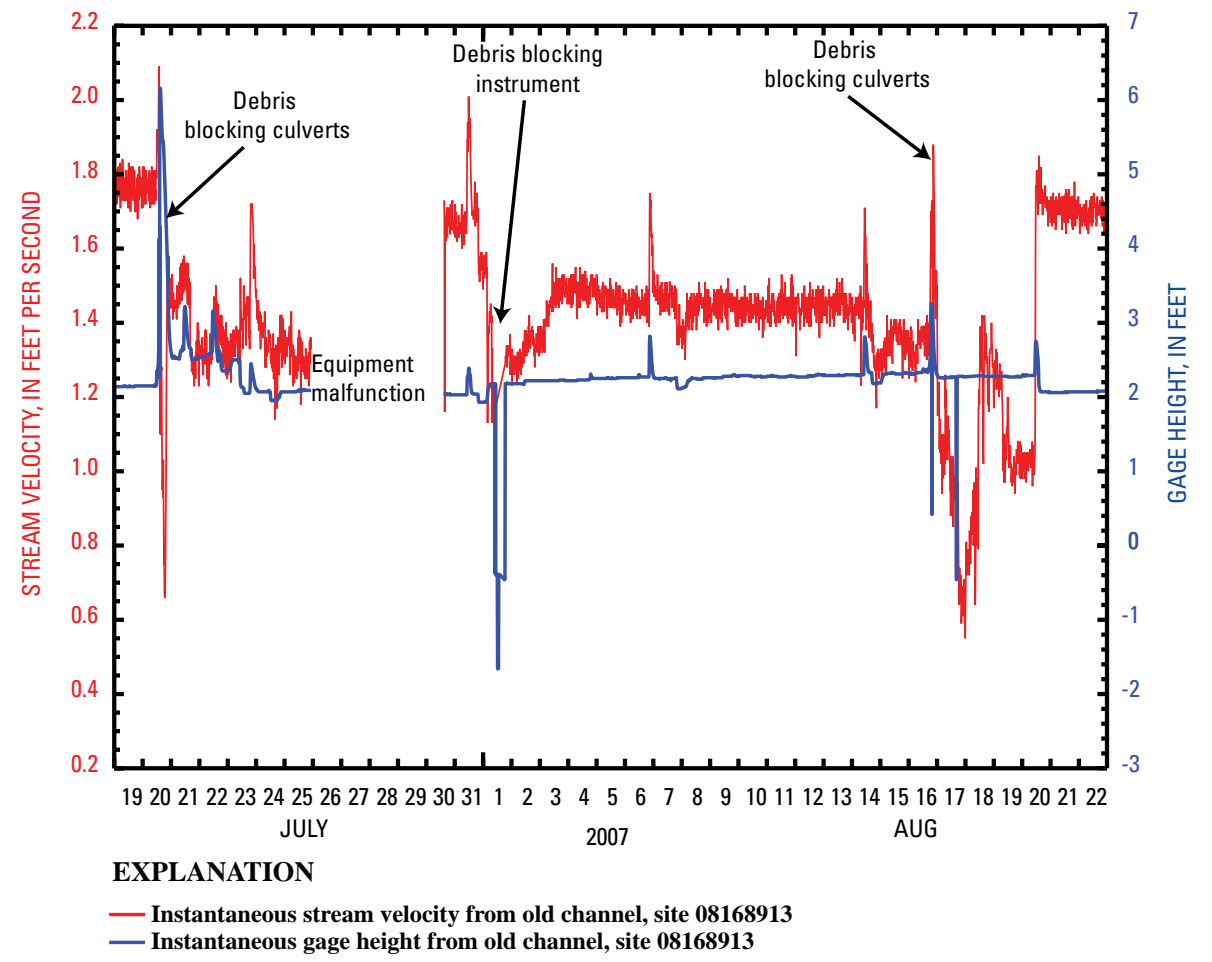

Figure 31. Velocity magnitude and gage height from old channel of Comal River showing influence of debris and anthropogenic control on streamflow. 


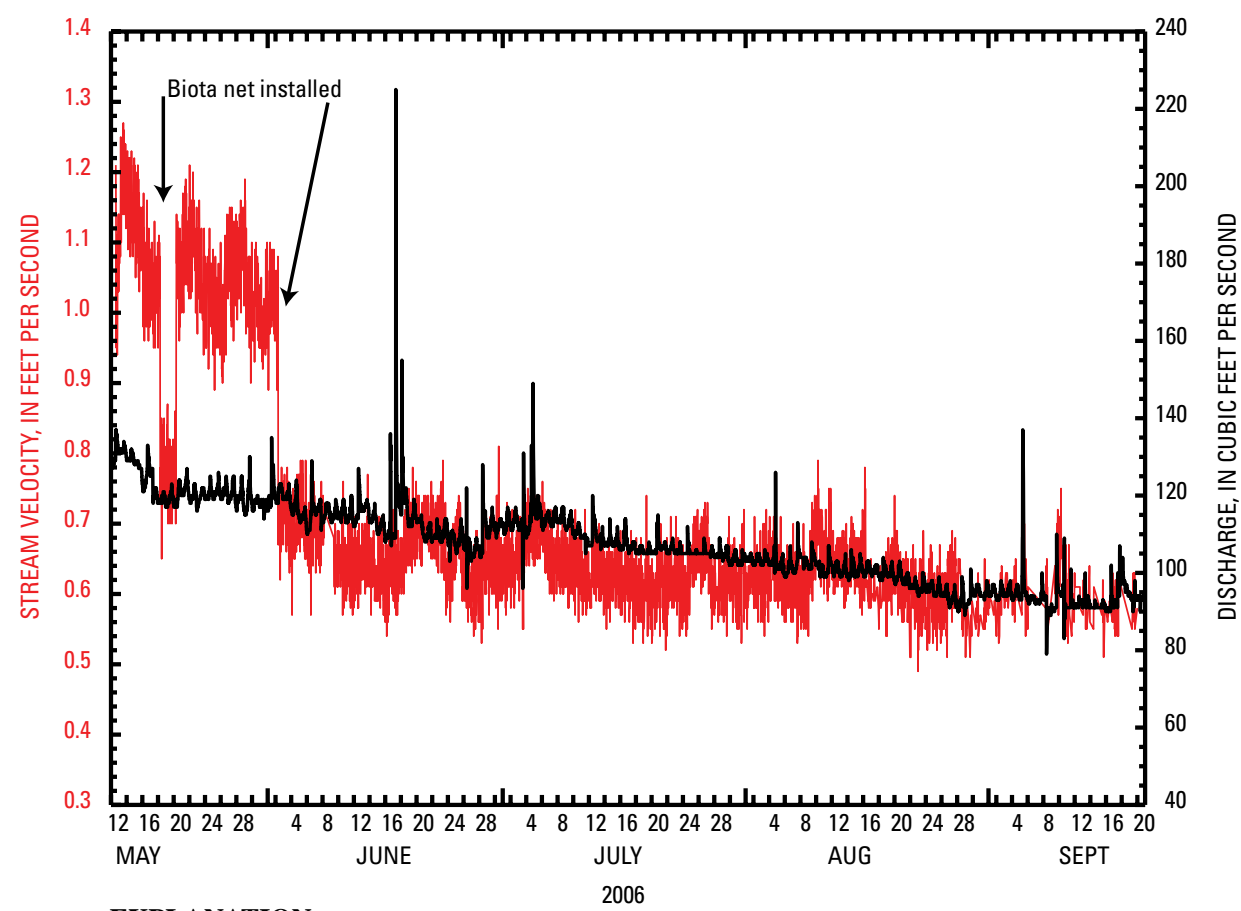

EXPLANATION

— Instantaneous stream velocity in pipe from diversion spring, site 295336097555201 (LR-67-01-825)

— Instantaneous discharge from San Marcos River at San Marcos, site 08170500

Figure 32. Velocity magnitude in pipe from diversion spring at San Marcos Springs and streamflow from station 08170500 San Marcos River at San Marcos during acoustic Doppler velocity meter deployment.

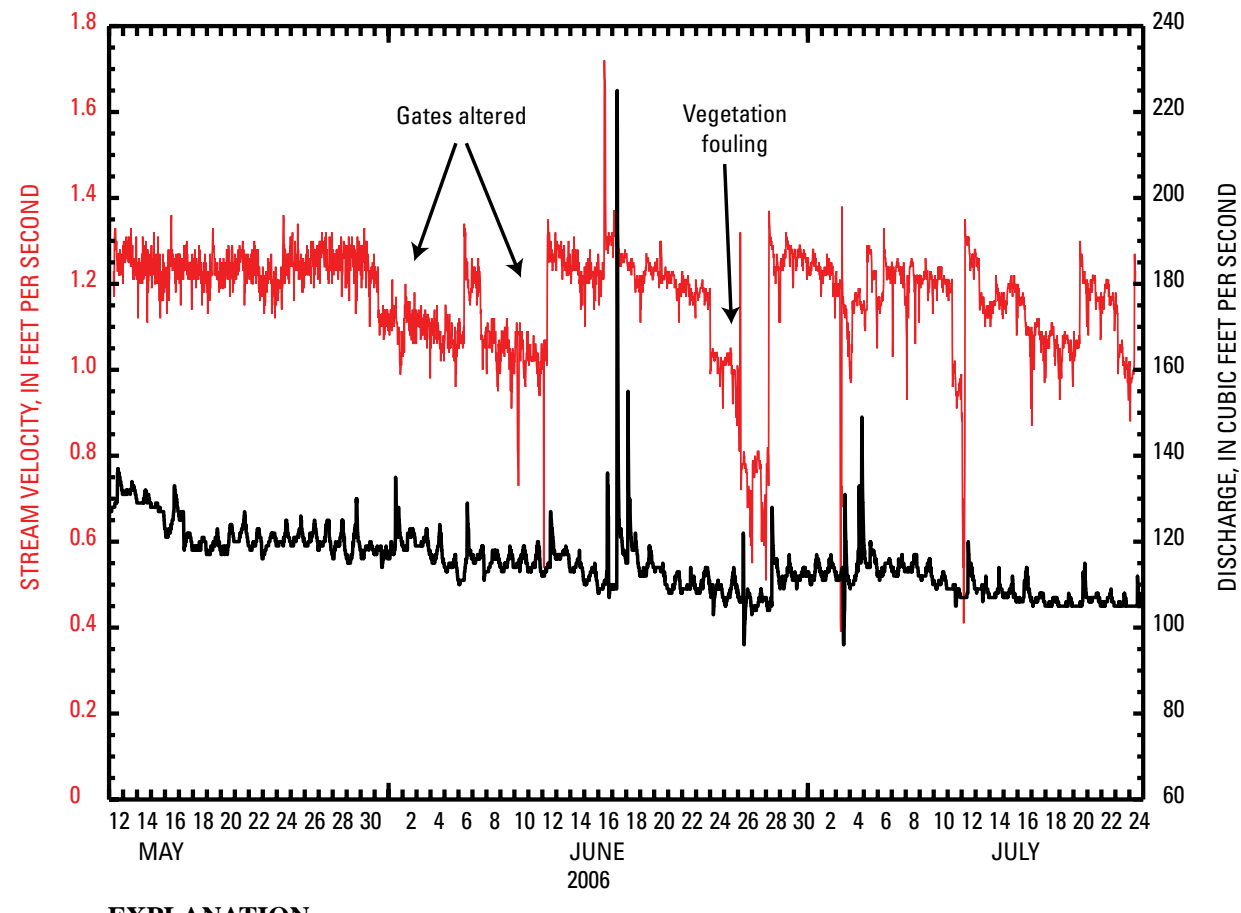

EXPLANATION

— Instantaneous stream velocity from west outflow of Spring Lake, site 08169945

— Instantaneous discharge from San Marcos River at San Marcos, site 08170500

Figure 33. Velocity magnitude from west outflow of Spring Lake and streamflow from station 08170500 San Marcos River at San Marcos during acoustic Doppler velocity meter deployment. 
east site. The Argonaut SL installed at the west site collected velocity data from May through July 2006. Two conditions that adversely affected the velocity record (fig. 33) precluded obtaining an accurate record at this site: (1) the gates at the dam were altered multiple times, which created substantial shifts in the data, and (2) Texas wild rice in the path of the acoustic beams of the ADVM intermittently reduced the recorded values by about 50 percent. Because Texas wild rice is an endangered species, it could not be removed or trimmed to clear a path for the acoustic beams. ADVM application at this site would not be particularly effective for obtaining data with the potential to increase accuracy of real-time springflow estimates.

\section{San Marcos Springs-East Outflow}

The east outflow channel from Spring Lake is free of structures that can be easily altered (like the gates at the west outflow), and no Texas wild rice is in this section of the lake; thus the east outflow channel site is more favorable for gaging than the west site. Data were collected at the east site from June 2006 through March 2007, and the velocity magnitude tracks reasonably well with streamflow from the San Marcos River gage 500 feet downstream (fig. 34). During many periods, the velocity data shifted downward because of vegetation fouling the sensor guard. Another problem at this site is high data noise of about 0.5 foot per second on average, the cause of which is unknown. The noise range is about 50 percent of the total measured velocity (fig. 35), which makes a potential relation between ADVM-recorded velocity at this site and total San Marcos Springs flow problematic.

\section{San Marcos Springs-San Marcos River Streamflow Gage}

Shifts in the streambed and density of vegetation at this site cause problems (for example, changes in stage for a given discharge) in obtaining an accurate record of streamflow, which currently (2008) is used to estimate real-time San Marcos Springs flow. The measurement of velocity by the ADVM at this site allows for two variables (stage and velocity) to be incorporated into the flow computation, thus potentially improving accuracy. For example, if the stream channel becomes obstructed with vegetation that causes a rise in stage, then the flow computation using stage only (the stage-discharge rating) would result erroneously in an increase in flow. However, ADVM velocity would decrease under the channel condition described, indicating correctly that flow had decreased.

Velocity from the ADVM at station 08170500 was recorded from July 2006 through September 2007 (fig. 36). A comparison of the computed discharge record during low-flow conditions in late summer 2006 (fig. 37) shows variation in the stage-discharge and the index-velocity ratings. The stagedischarge values have been corrected by applying a shift in stage; no shifts have been applied to the index-velocity values. The uncorrected index-velocity values show variability relative to the corrected stage-discharge values: During August through mid-September the index-velocity values are close to discharge computed using the corrected stage-discharge with some periods of higher computed discharge and some periods lower computed discharge; from mid-September through October the uncorrected index-velocity values are consistently greater than the corrected stage discharge. This might indicate discrepancies in the current (2008) shifting-control method used in the stage-discharge rating and that shifts are required to correct the index-velocity rating at this site, as with the stage-discharge rating.

The index-velocity discharge values also show more variability between each instantaneous value than the stagedischarge values. This is because two variables are used in the discharge equation (index-velocity discharge) rather than one (stage-discharge).

\section{Implications of Findings Pertaining to Improving Real-Time Springflow Estimates}

\section{Comal Springs}

The findings indicate that ADVMs at the Comal River new channel site (08168932 Comal River [new channel] near Landa Lake, New Braunfels,) and old channel site (08168913 Comal River [old channel] near Landa Lake, New Braunfels) provide data that potentially could yield more accurate real-time estimates of total Comal Springs flow than currently (2008) are available from streamflow measured at station 08169000. The sum of the flow from these two channel stations, which were newly established for this study, provides an independent check on the springflow recorded at station 08169000 farther downstream. The measurement of velocity at the two sites, in conjunction with stage and a discharge/ velocity-stage-index rating at each, would allow accurate estimation of flow in the channels.

The combination of two velocity measurements at the new channel site, one at the weir and one in the bypass pipe, provide direct observation of the status of the valve controlling flow in the bypass pipe; and stage at this site provides constraints on the hydraulic computations over the weir and through the pipe. Hydraulic computations of flow over weirs and in pipes provide straightforward analytical structure for the incorporation of velocity and stage data for collection of springflow data. The measurement of velocity at the old channel site, together with stage, provides direct observation of the condition of the flow through the culverts immediately downstream from the site. A combination of conventional stage-discharge and discharge/velocity-stage-index ratings at both new channel and old channel sites can provide accurate springflow values. The channel sites are considered 


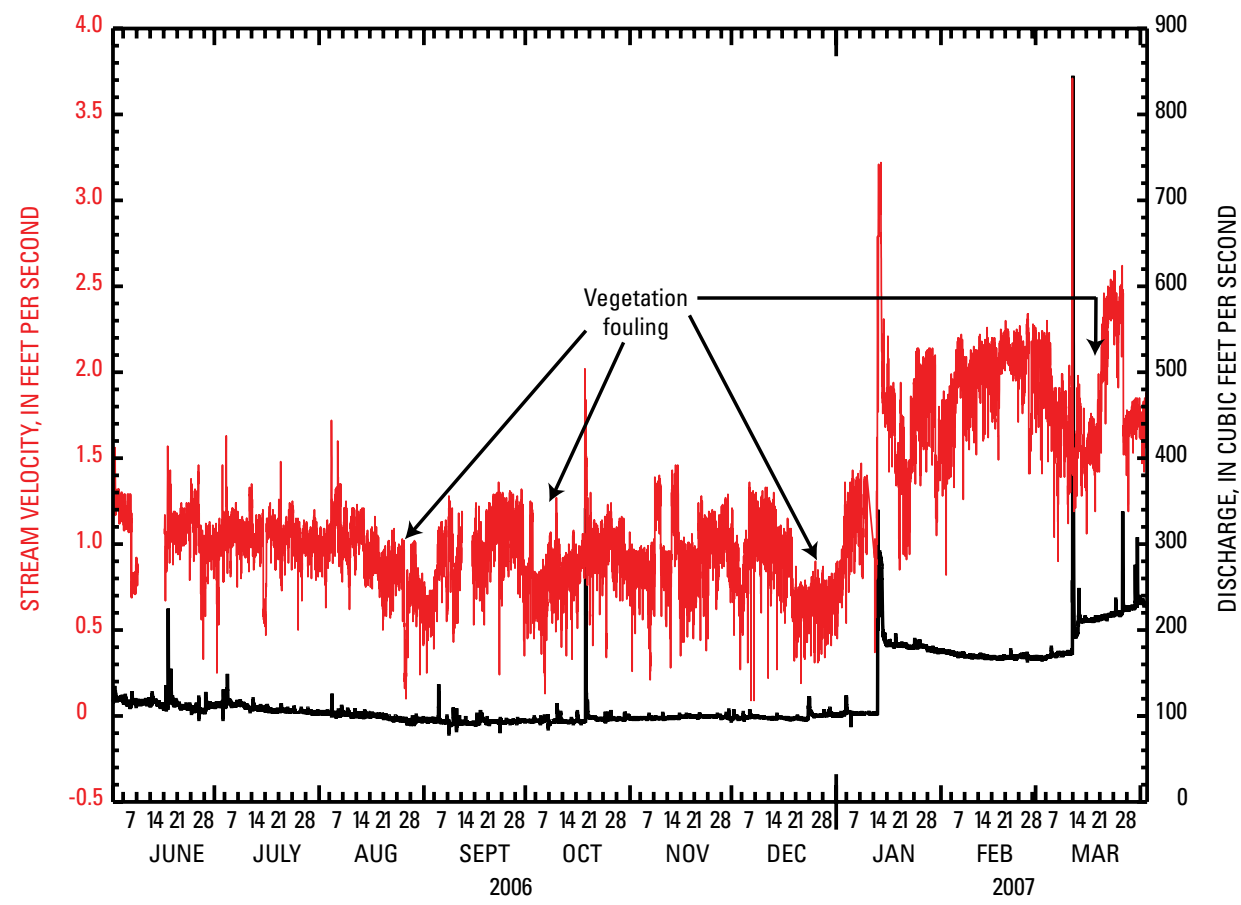

EXPLANATION

- Instantaneous stream velocity from east outflow of Spring Lake, site 08169944

- Instantaneous discharge from San Marcos River at San Marcos, site 08170500

Figure 34. Velocity magnitude from east outflow of Spring Lake and streamflow from station 08170500 San Marcos River at San Marcos during acoustic Doppler velocity meter deployment.

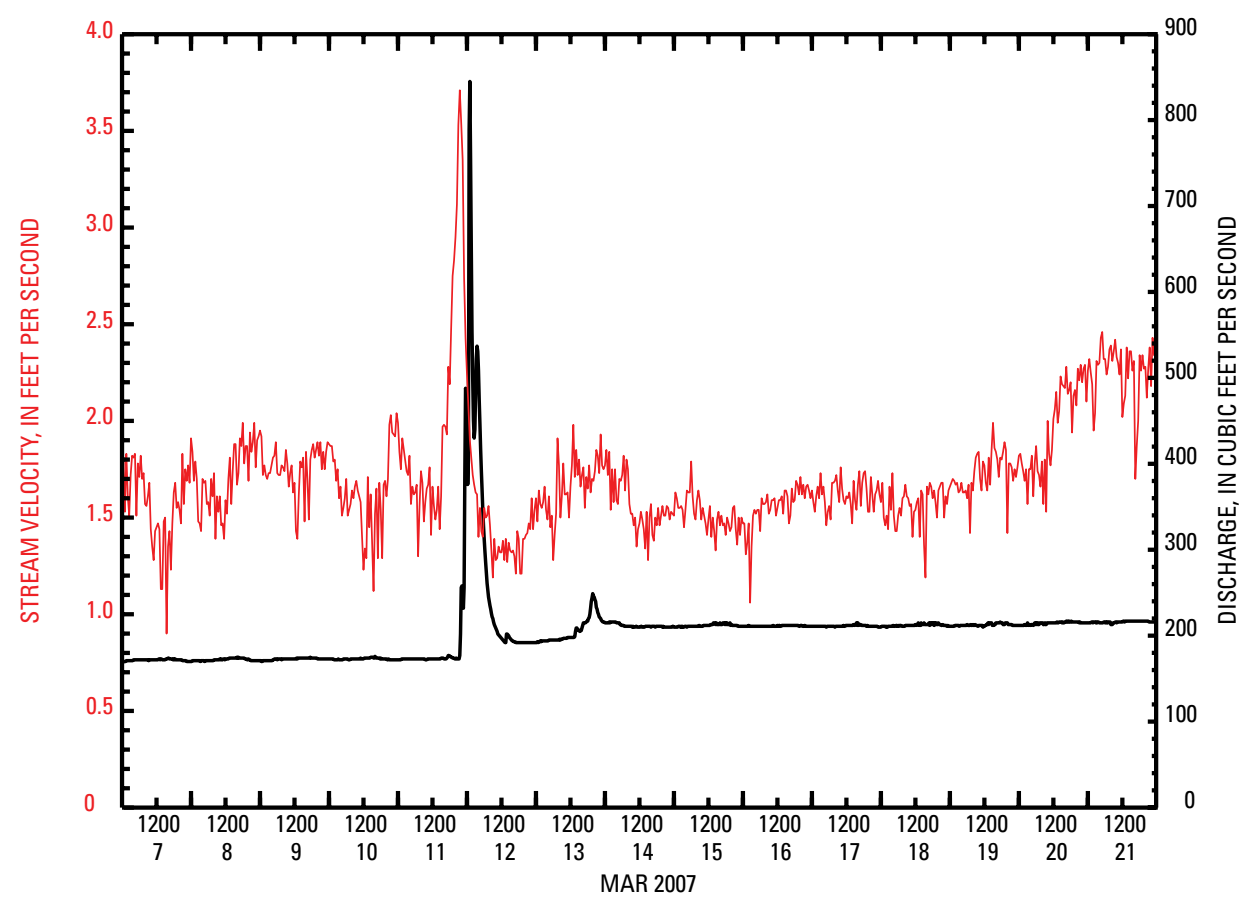

EXPLANATION

— Instantaneous stream velocity from east outflow of Spring Lake, site 08169944

— Instantaneous discharge from San Marcos River at San Marcos, site 08170500

Figure 35. Velocity magnitude from east outflow of Spring Lake and streamflow from station 08170500 San Marcos River at San Marcos, March 7-21, 2007. 


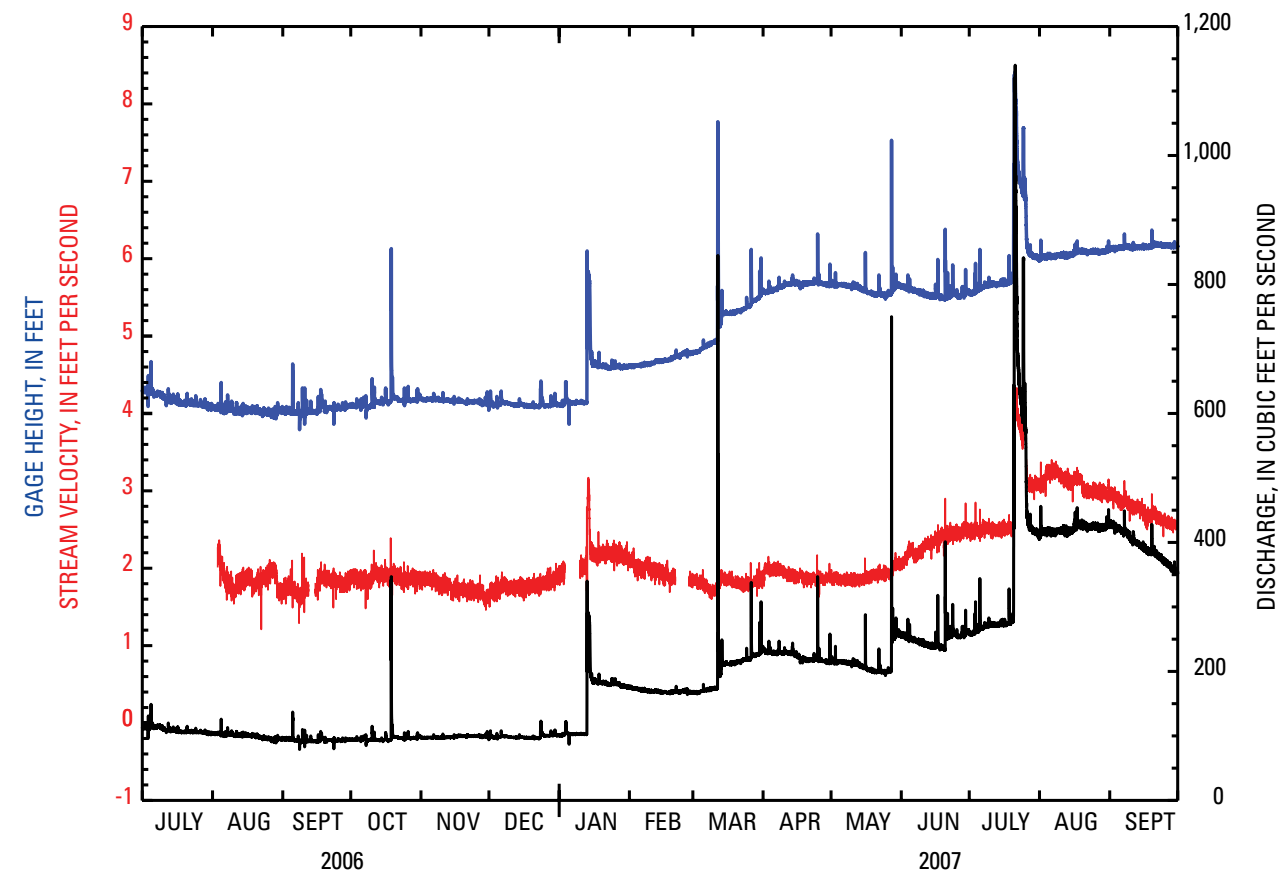

EXPLANATION

- Instantaneous stream velocity (x-direction only) from San Marcos River at San Marcos, site 08170500

- Instantaneous gage height from San Marcos River at San Marcos, site 08170500

— Instantaneous discharge from San Marcos River at San Marcos, site 08170500

Figure 36. Velocity, gage height, and streamflow from station 08170500 San Marcos River at San Marcos during acoustic Doppler velocity meter deployment.

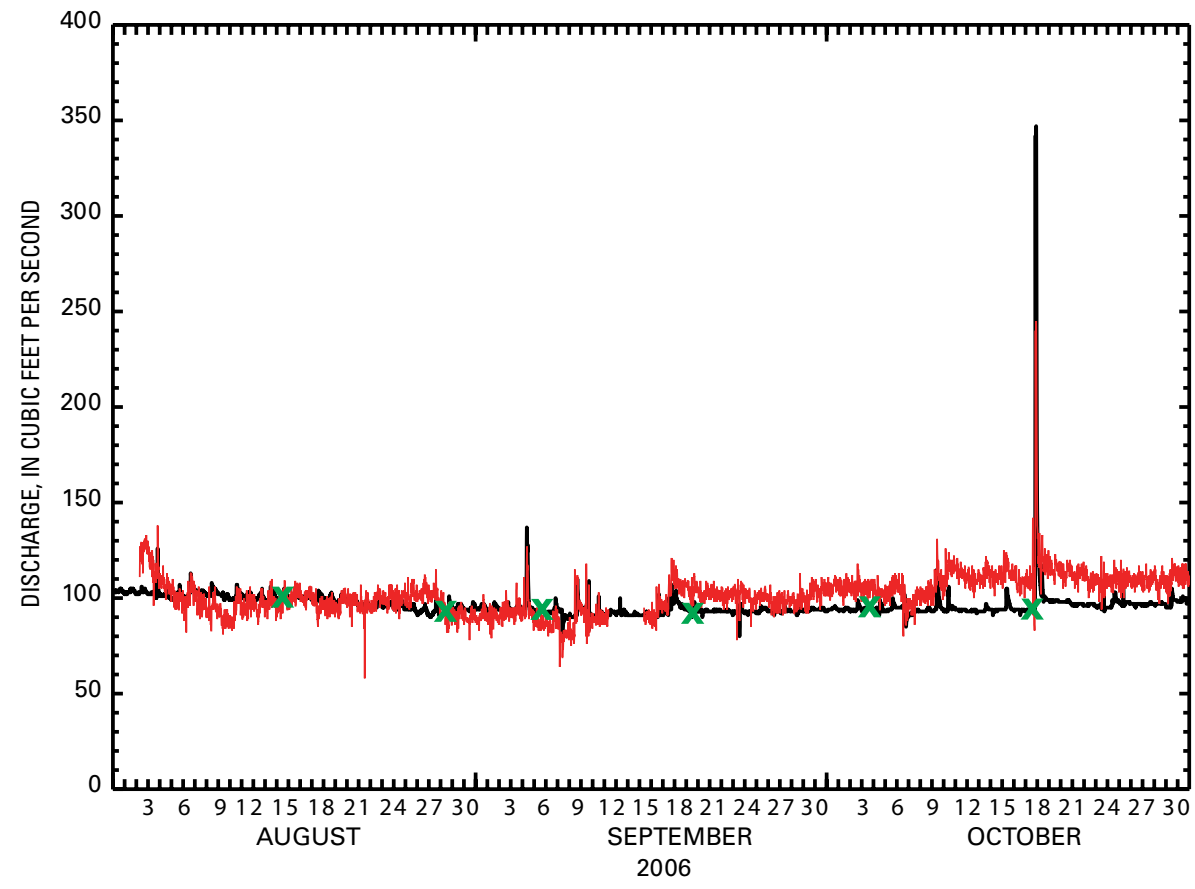

EXPLANATION

- Instantaneous discharge from San Marcos River at San Marcos, site 08170500, computed from stage-discharge rating

- Instantaneous discharge from San Marcos River at San Marcos, site 08170500, computed from index-velocity rating

X Instantaneous discharge from San Marcos River at San Marcos, site 08170500, direct discharge measurements

Figure 37. Streamflow from station 08170500 San Marcos River at San Marcos, August 1-0ctober 31, 2006. 
excellent (new channel) and good (old channel) for monitoring flow, and each site is safely and readily maintainable by divers. The sites also are reasonably isolated from public intrusion.

The simultaneous operation of the new channel, old channel, and river stations can enhance the quantification of total flow from Comal Springs and would provide data redundancy that could prove important during critical (lowflow) flow conditions. The sum of flows for the new channel and old channel stations provides a real-time estimate of springflow that is likely closer to the true flow of Comal Springs than streamflow measured at the river gage downstream.

\section{San Marcos Springs}

The findings indicate shortcomings with ADVM installations at diversion spring (uncertainty associated with the biota net installation and its influence on velocity measurements), in the west outflow channel from Spring Lake (data shifts associated with downstream gate alterations and vegetation issue), and in the east outflow channel (vegetation issue and unexplained noise in recorded velocity data). However, the accuracy of streamflow from station 08170500 as an estimate of real-time San Marcos Springs flow could potentially be increased through use of ADVM data from that site. Furthermore, flow computed from ADVM velocity data could provide an independent check on flow computed by conventional methods for station 08170500 , the computation of which can be challenging because changes in vegetation density and gravel movement can affect the stage-discharge rating.

\section{Summary}

Comal Springs in Comal County and San Marcos Springs in Hays County are the two largest springs in Texas and are major discharge points for the San Antonio segment of the Edwards aquifer in Central Texas. Springflows (discharges) of Comal and San Marcos Springs indicate critical aquifer conditions relative to the survival of several Federally listed endangered species. When springflows decrease below specific thresholds, the Edwards Aquifer Authority (EAA) initiates restrictions on withdrawals (pumping) of water from the aquifer to protect endangered species. It is therefore imperative that the EAA have accurate and timely springflow data to guide resource management.

Flows from Comal Springs and San Marcos Springs emanate from many distributed and focused discharge points submerged in Landa Lake at Comal Springs and in Spring Lake at San Marcos Springs. Flows from the springs currently (2008) are estimated by the U.S Geological Survey (USGS) in real time as streamflow computed from stage-discharge ratings at USGS station 08169000 about 1.6 miles downstream from the major spring orifices at Landa Lake and station 08170500 about 0.5 mile downstream from the major spring orifices at Spring Lake. Streamflow gains and losses that periodically occur in the stream reaches between the springs and the gaging stations cause streamflows measured at the stations to not always reflect true springflows.

Recent technological advances and availability of acoustic Doppler velocity meters (ADVMs) now provide tools to collect data (stream velocity) related to springflow that could increase accuracy of real-time estimates of flows from Comal and San Marcos Springs. The USGS, in cooperation with the EAA, did a study during May 2006 through September 2007 to evaluate ADVMs to quantify flow from Comal and San Marcos Springs, with the overall objective of improving methods of flow measurement and thus estimates of total springflow for each spring. Eight sites were equipped with ADVMs for periods of months during 2006-07 to evaluate the performance of ADVMs: one ADVM each at three sites and two ADVMs at one site at Comal Springs; and one ADVM each at four sites at San Marcos Springs.

The evaluation was based on two monitoring approaches: (1) Placement of ADVMs in important spring orifices to measure flow directly at discrete discharge points. Two sites at Comal Springs, spring run 3, and spring 7, and one site at San Marcos Springs, diversion spring, were monitored using this approach. (2) Placement of ADVMs at the nearest flowing streams to measure total springflow as outflow from Landa Lake and Spring Lake. At Comal Springs, ADVMs were installed in the new channel and the old channel of the Comal River, which originates at Landa Lake. At San Marcos Springs, both west and east outflow channels at Spring Lake were instrumented with ADVMs, as well as existing station 08170500 on the San Marcos River.

For Comal Springs, ADVM application at spring run 3 and spring 7 was intended to indicate whether the flows of spring run 3 and spring 7 can be related to total springflow. The findings indicate that even though velocity data from both discharge features reflect changes in flow, the data do not reliably show a direct relation to streamflow at station 08169000 Comal River at New Braunfels, and thus to total Comal Springs flow, assuming that total springflow is indicated by streamflow at station 08169000.

ADVMs at the Comal River new channel site and old channel site provide data that potentially could yield more accurate real-time estimates of total Comal Springs flow than currently (2008) are available from streamflow measured at station 08169000 . The sum of flows for the new channel and old channel stations provides a real-time estimate of springflow that is likely closer to the true flow of Comal Springs than streamflow measured at station 08169000 downstream. This potential increase in accuracy is in large part because distance between the springs and ADVM flow-measuring sites is less than that between the springs and station 08169000 , which in turn reduces the effects of streamflow gains (primarily) and losses on estimates of springflow. The sum of the flow from these two channel stations can provide an independent 
check on the springflow recorded at station 08169000 farther downstream, and simultaneous operation of all three stations would provide data redundancy that could prove important during critical (low-flow) flow conditions.

For San Marcos Springs, the findings indicate shortcomings with ADVM installations at diversion spring (uncertainty associated with the biota net installation and its influence on velocity measurements), in the west outflow channel from Spring Lake (data shifts associated with downstream gate alterations and vegetation issue), and in the east outflow channel (vegetation issue and unexplained noise in recorded velocity data). However, the accuracy of streamflow from station 08170500 as an estimate of real-time San Marcos Springs flow could potentially be increased through use of ADVM data from that site. And, flow computed from ADVM velocity data could provide an independent check on flow computed by conventional methods for station 08170500 , the computation of which can be challenging because changes in vegetation density and gravel movement can affect the stage-discharge rating.

\section{References}

Asquith, W.H., and Gary, M.O., 2005, Acoustic Doppler velocity monitoring within Main Spring, Barton Springs, Austin, Texas, April-September 2004-Enhancing the accuracy of springflow data: U.S. Geological Survey Fact Sheet 2005-3044, 4 p.

Crowe, J.C., and Sharp, J.M., Jr., 1997, Hydrogeologic delineation of habitats for endangered species-The Comal Springs/River system: Springer-Verlag, Environmental Geology, v. 30, no. 1-2, p. 17-28.

Gary, M.O., 2007, Establishing temporal trends-The first two years of continuous monitoring at Jacob's Well Spring, Woodcreek, Texas [abs.], in 15th National Nonpoint Source Monitoring Workshop-Monitoring for decision making, Austin, Texas, August 26-30, 2007, Proceedings: U.S. Environmental Protection Agency, Texas Commission on Environmental Quality, River Systems Institute, 1 p.

Gary, M.O., and Asquith, W.A., 2005, Monitoring springs in karst aquifers [abs.], in The Abstract Book of the 2005 Ground Water Summit Program, San Antonio, Texas, April 17-20, 2005: National Ground Water Association, p. 241.

Gary, M.O., and Asquith, W.H., 2006, Karst spring monitoring using acoustic Doppler velocity data, in Geological Society of America, Annual Meeting \& Exposition, Philadelphia, Pennsylvania, October 22-25, 2006: Topical Session T74, paper 74-3.
Kreitler, C.W., Davidson, Tyler, Hamilton, Mark, Schindel, Geary, and Johnson, Steve, 2004, Hydrogeologic characterization of Comal Springs during low flow periods, Edwards aquifer, Texas-Implications to sustaining spring flow through aquifer management and spring augmentation [abs.], in Geological Society of America, 2004 Annual Meeting, Denver, Colorado, November 7-10, 2004: Abstracts with Programs, v. 36, no. 5, p. 391.

LBG Guyton Associates, 2004, Evaluation of augmentation methodologies in support of in-situ refugia at Comal and San Marcos Springs, Texas: San Antonio, report prepared for Edwards Aquifer Authority, $192 \mathrm{p}$.

Morlock, S.E., Nguyen, H.T., and Ross, J.H., 2002, Feasibility of acoustic Doppler velocity meters for the production of discharge records from U.S. Geological Survey streamflowgaging stations: U.S. Geological Survey Water-Resources Investigations Report 01-4157, 56 p.

Rantz, S.E., and others, 1982, Measurement and computation of streamflow-Volume 1, Measurement of stage and discharge. Volume 2, computation of discharge: U.S. Geological Survey Water-Supply Paper 2175, 630 p.

SonTek Corporation, 2000, SonTek Argonaut-series instruments technical documentation: San Diego, SonTek Corporation, $77 \mathrm{p}$.

SonTek Corporation, 2007, Argonaut-SW specifications: accessed January 23, 2008, at http://www.sontek.com/ download/brochure/arg-sw.pdf

U.S. Fish and Wildlife Service, 1996, San Marcos and Comal Springs and associated aquatic ecosystems (revised) recovery plan: U.S. Fish and Wildlife Service report, 121 p.

U.S. Geological Survey, 2007, Office of Surface Water (OSW) hydroacoustics-Acoustic Doppler velocity meters: accessed November 16, 2007, at http://hydroacoustics.usgs. gov/indexvelocity/instruments.shtml

U.S. Geological Survey, 2008, National Water Information System (NWISWeb) data available on the World Wide Web at $h t t p: / / w a t e r d a t a . u s g s . g o v / t x / n w i s / n w i s$

Wahl, K.L., and Wahl, T.L., 1995, Determining the flow of Comal Springs at New Braunfels, Texas, in Texas Water '95, A Component Conference of the First International Conference on Water Resources Engineering, San Antonio, Texas, August 16-17, 1995, Proceedings: American Society of Civil Engineers, p. 77-86.

Zara Environmental LLC, 2005, Diversion spring cave: San Antonio, report prepared for Edwards Aquifer Authority, $12 \mathrm{p}$. 
Blank Page 


\section{Appendix 1-Acoustic Doppler Velocity Meter Data}


Blank Page 


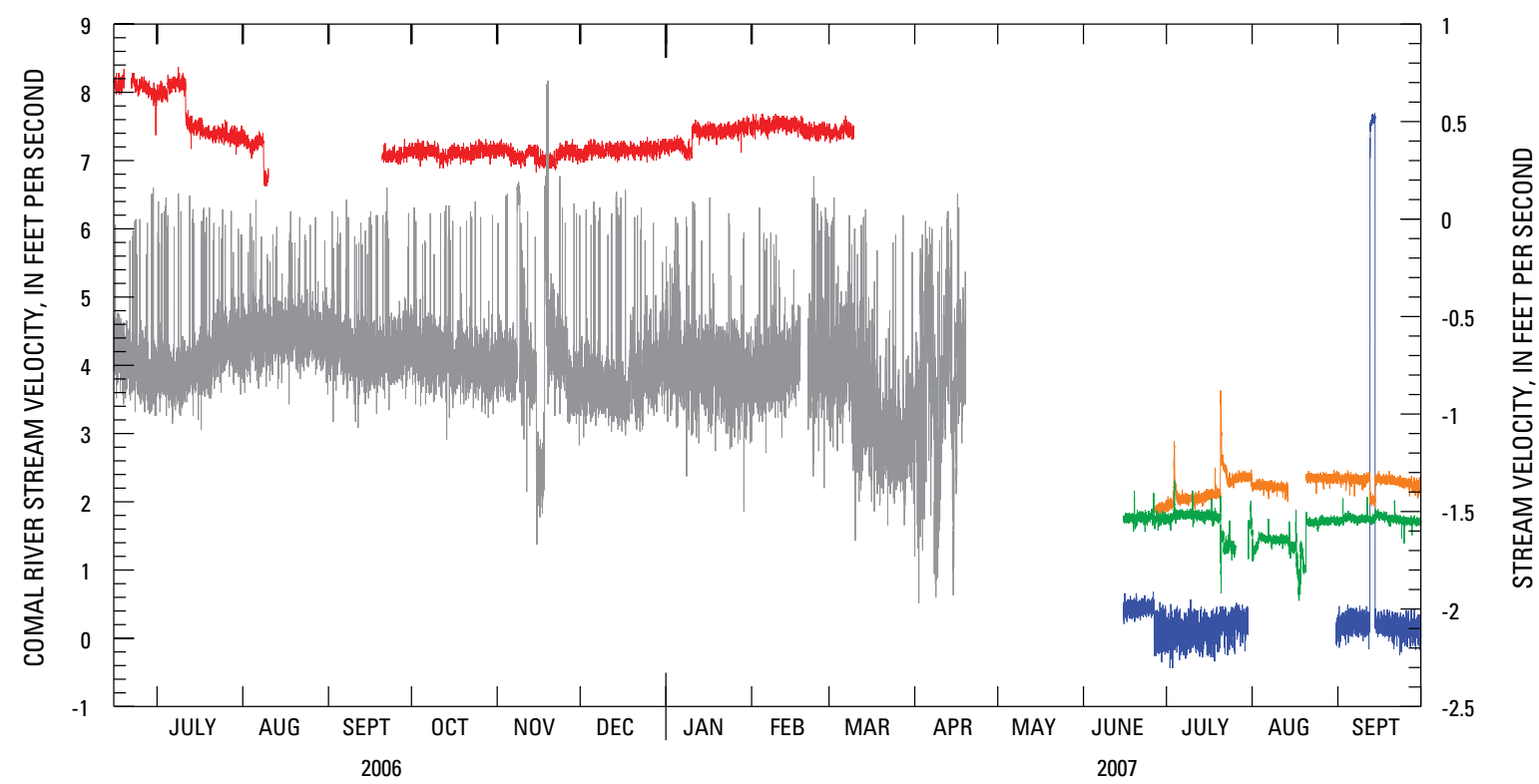

EXPLANATION
Stream velocity magnitude in bypass pipe from new channel, site 08168932
Stream velocity magnitude over weir from new channel, site 08168932
Stream velocity magnitude from old channel, site $\mathbf{0 8 1 6 8 9 1 3}$
Stream velocity magnitude from spring run 3, site 294250098080900 (DX-68-23-321)
Stream velocity ( $x$-direction only) from spring 7, site 294255098080501 (DX-68-23-324)

Figure 1.1. Hydrograph showing all stream velocity data collected using acoustic Doppler velocity meters at monitoring sites at Comal Springs, New Braunfels, Texas.

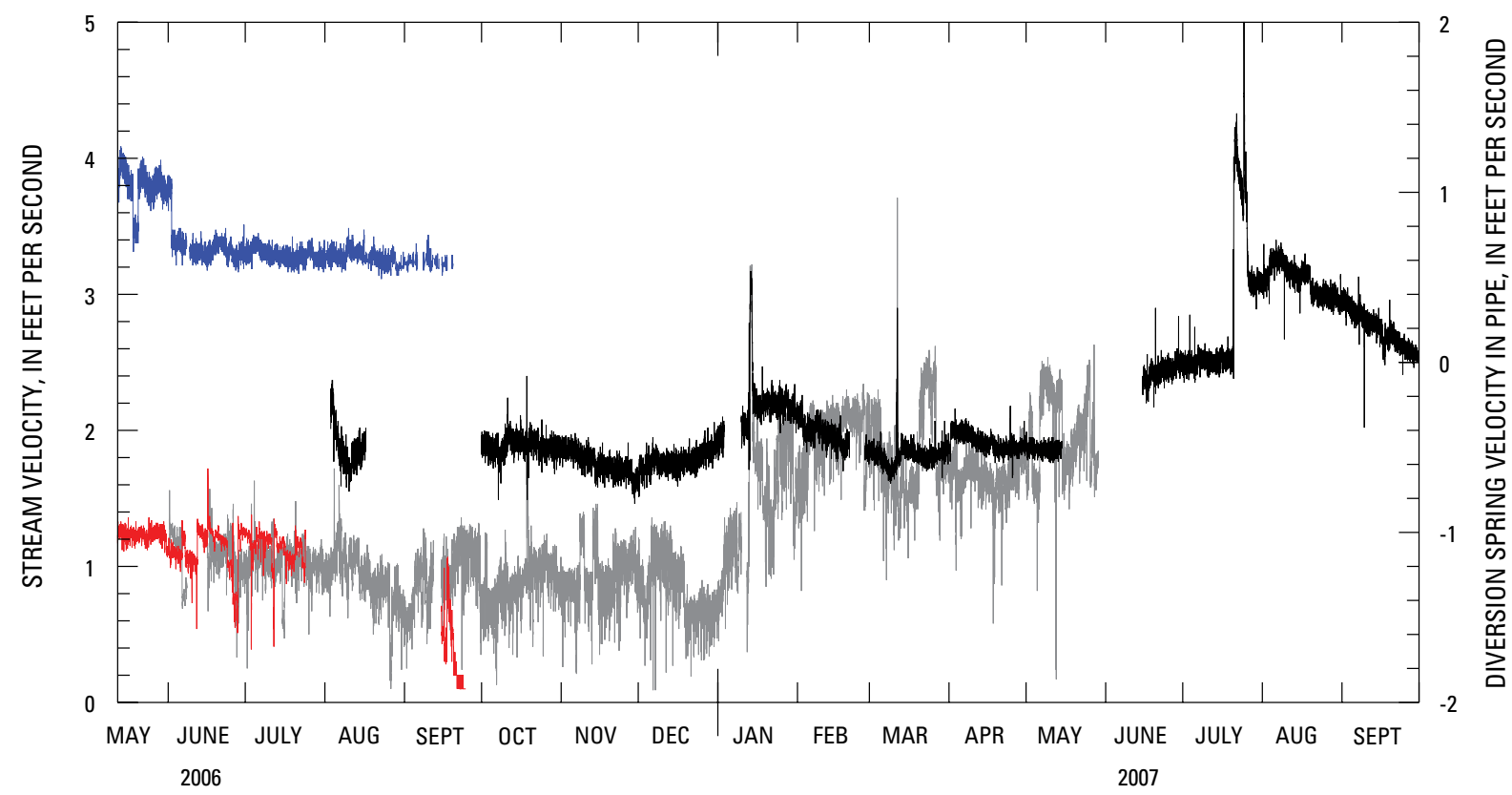

EXPLANATION

_ Stream velocity magnitude from east outflow of Spring Lake, site 08169944

Stream velocity magnitude from west outflow of Spring Lake, site 08169945

Stream velocity magnitude from San Marcos River at San Marcos, site 08170500

Stream velocity magnitude in pipe from diversion spring, site 295336097555201 (LR-67-01-825)

Figure 1.2. Hydrograph showing all stream velocity magnitude data collected using acoustic Doppler velocity meters at monitoring sites at San Marcos Springs, San Marcos, Texas. 


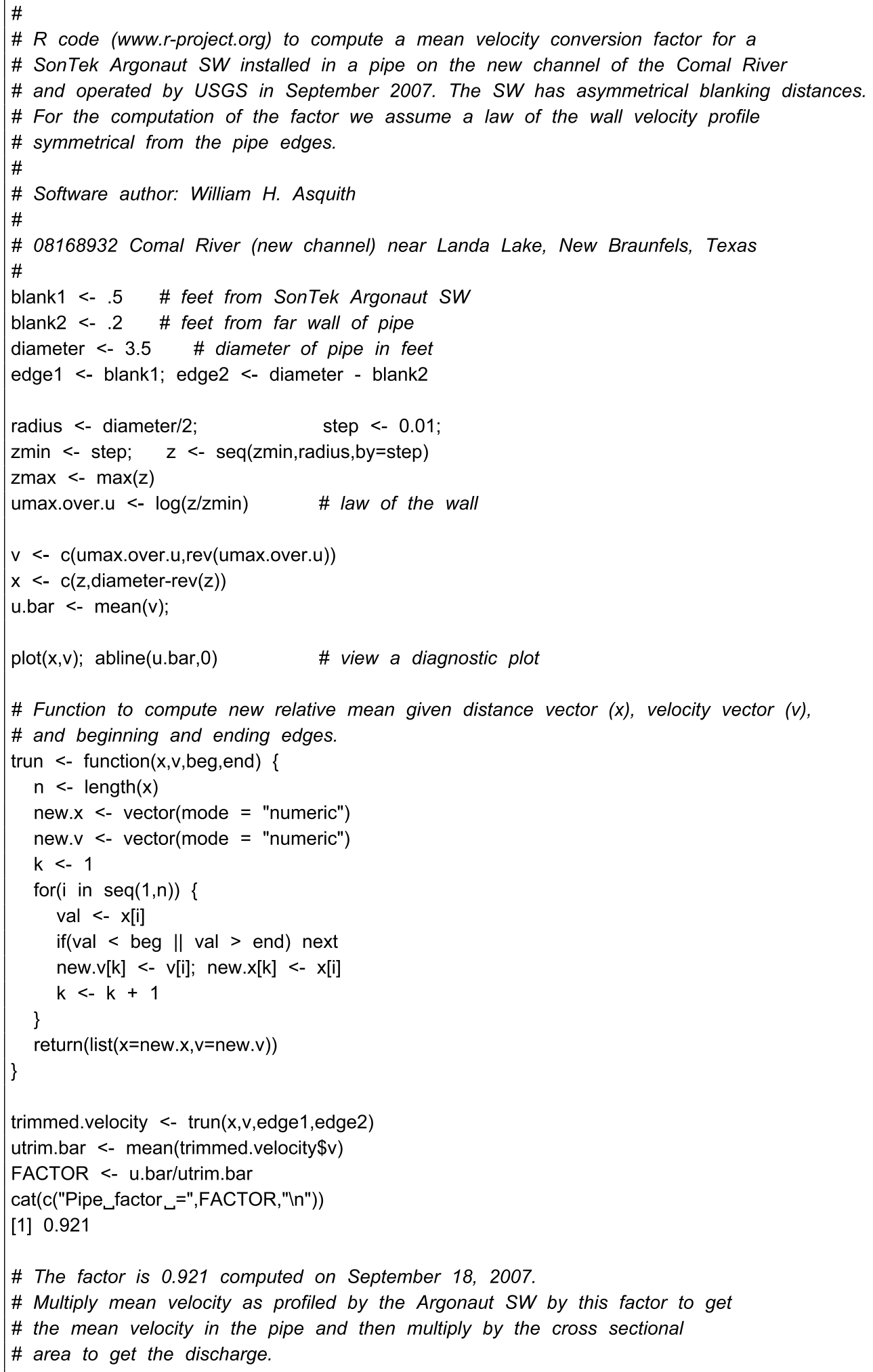

Figure 1.3. Listing of $\mathrm{R}$ code for computation of a mean velocity correction factor for bypass pipe at station 08168932 Comal River (new channel) near Landa Lake, New Braunfels, Texas, based on pipe geometry and settings of Argonaut SW. 
Appendix 1 files (Online only at http://pubs.usgs.gov/sir/2008/5083)

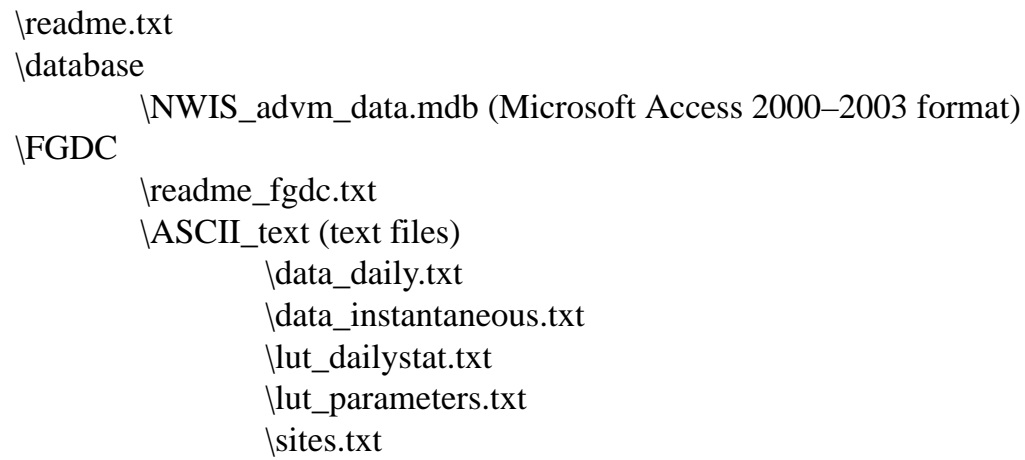

